\title{
Inuit Knowledge of Long-term Changes in a Population of Arctic Tundra Caribou
}

\author{
MICHAEL A.D. FERGUSON ${ }^{1}$, ROBERT G. WILLIAMSON² and FRANÇOIS MESSIER ${ }^{3}$
}

(Received 2 October 1996; accepted in revised form 25 November 1997)

\begin{abstract}
Indigenous peoples possess knowledge about wildlife that dates back many generations. Inuit observations of historical changes in a caribou population on southern Baffin Island, collected from 43 elders and active hunters during 198395, indicate that caribou were abundant and their distributions extensive in most coastal areas of southern Baffin Island from c.1900-25. Subsequently, caribou distributions contracted and abundance declined, probably reaching an overall low in the 1940s. Beginning in the mid-1950s, distributions and abundance increased gradually, at least until the mid-1980s. Changes in distribution occurred mainly during autumn, as caribou migrated to their wintering areas. Within most wintering areas, increases in caribou abundance followed a process of range expansion, range drift (i.e., expanding on one front while contracting on another), and finally range shift (i.e., mass emigration to a new winter range). During the population decline and low, the caribou often exhibited winter range volatility (i.e., frequent, unpredictable interannual range shifts). On the basis of Inuit descriptions of caribou abundance, we estimated that the population as a whole decreased an average of 9\% annually from 1910 to 1940, and then increased about 8\% annually from 1940 to 1980. This pattern was largely consistent across southern Baffin Island. As Inuit elders had predicted in 1985, the population essentially abandoned its highest-density wintering area on Foxe Peninsula during the late 1980s, apparently emigrating en masse to a new wintering area on Meta Incognita Peninsula, about $375 \mathrm{~km}$ to the southeast. Inuit knowledge suggested that caribou population fluctuations are cyclic, with each full cycle occurring over the lifetime of an elder. Both this study and historical records dating from 1860 support a periodicity of 60-80 years for fluctuations of the South Baffin caribou population. Inuit elders suggested that the abundance of caribou on wintering areas decreases several years after caribou occupy small coastal islands, a phenomenon currently occurring throughout southern Baffin Island, except on Cumberland Peninsula. The Inuit recognize two ecotypes of caribou: migratory upland-lowland caribou and resident mountainplateau caribou. After migratory caribou from Foxe Peninsula shifted their winter range around 1990, Meta Incognita Peninsula was occupied by both ecotypes. The migratory caribou apparently occupy low elevations, while the resident caribou remain in the mountains, producing two seasonal migratory patterns. Inuit knowledge proved to be temporally and spatially more complete than the written record.
\end{abstract}

Key words: Inuit, traditional ecological knowledge, caribou, Rangifer tarandus, population dynamics, metapopulations, Baffin Island, Nunavut, Canada

RÉSUMÉ. Les peuples autochtones possèdent des connaissances sur la faune qui remontent à des générations. Les observations inuit sur les changements historiques survenus dans une population de caribous dans la partie méridionale de l'île de Baffin recueillies auprès de 44 anciens et chasseurs en activité entre 1983 et 1995 révèlent que, d'environ 1900 à 1925, le caribou était abondant et réparti sur une vaste superficie dans la plupart des zones côtières du sud de l'île de Baffin. Par la suite, le domaine du caribou s'est rétréci et l'animal a diminué en nombre, atteignant probablement son niveau le plus bas dans les années 1940. À partir du milieu des années 1950, la distribution et le nombre d'animaux ont augmenté graduellement, au moins jusqu' au milieu des années 1980. La distribution changeait surtout durant l'automne, quand le caribou migrait vers ses aires d'hivernage. Dans la plupart des aires d'hivernage, l'augmentation du nombre de caribous suivait un processus d'expansion du territoire, de dérive du territoire (c.-à-d. expansion sur un front en même temps que contraction sur un autre), et finalement de déplacement du territoire (c.-à-d. émigration généralisée du caribou vers une nouvelle aire d'hivernage). Durant la baisse et le minimum de population, l'aire du caribou se révélait souvent instable (c-.à-d. que d'une année à l' autre, l' animal changeait fréquemment de territoire, et ce, d'une façon imprévisible). En se fondant sur les descriptions inuit de l'abondance du caribou, on a estimé que l'ensemble de la population a baissé en moyenne de 9 p. cent par an de 1910 à 1940, puis augmenté de près de 8 p. cent par an de 1940 à 1980 . Ce schéma était à peu près identique dans toute la partie méridionale de l'île de Baffin. Comme les Inuit l'avaient prédit en 1985, la population a quasiment abandonné son aire d'hivernage à très forte densité sur la péninsule Foxe à la fin des années 1980, pour apparemment émigrer en masse vers une nouvelle aire d'hivernage sur la péninsule Meta Incognita située à environ $375 \mathrm{~km}$ au sud-est. Le savoir inuit suggérait que les fluctuations dans la population du caribou sont cycliques, chaque cycle complet couvrant la durée de vie d'un ancien. Cette étude, de même que les dossiers historiques datant de 1860, appuient une périodicité de 60 à 80 ans pour les

\footnotetext{
${ }^{1}$ Department of Resources, Wildlife and Economic Development, Government of the Northwest Territories, Pond Inlet, Northwest Territories X0A 0S0, Canada; BaffBio@nunanet.com

${ }^{2}$ Department of Anthropology, University of Saskatchewan, 55 Campus Drive, Saskatoon, Saskatchewan S7N 5B1, Canada.

${ }^{3}$ Department of Biology, University of Saskatchewan, 112 Science Place, Saskatoon, Saskatchewan S7N 5E2, Canada

(C) The Arctic Institute of North America
} 
fluctuations de la population du caribou du sud de Baffin. Les anciens inuit suggéraient que l'abondance du caribou dans les aires d'hivernage diminue plusieurs années après que l'animal a occupé les petites îles côtières, phénomène qui se passe actuellement dans toute la partie méridionale de l'île de Baffin, sauf dans la péninsule Cumberland. Les anciens inuit identifient deux écotypes de caribou: celui qui migre des hautes terres vers les basses terres et inversement et celui qui réside en permanence sur les montagnes et plateaux. Après que le caribou de la péninsule Foxe a changé d'aire d'hivernage vers 1990, la péninsule Meta Incognita a été occupée par les deux écotypes. Le caribou migrateur occupe apparemment les sites bas, tandis que le caribou sédentaire reste dans les montagnes, ce qui donne lieu à deux schémas migratoires saisonniers. Les connaissances des Inuit se sont avérées plus complètes que celles consignées dans les documents écrits, autant en ce qui concerne les données spatiales que temporelles.

Mots clés: Inuit, savoir écologique traditionnel, caribou, Rangifer tarandus, dynamique des populations, métapopulations, île de Baffin, Nunavut, Canada

Traduit pour la revue Arctic par Nésida Loyer.

\section{INTRODUCTION}

Historically, caribou (Rangifer tarandus) in Alaska (Skoog, 1968), the mainland of the Northwest Territories (NWT) (Parker, 1972), northern Québec (Messier et al., 1988; Crête and Payette, 1990), Greenland (Meldgaard, 1986), and Bathurst Island (Tener, 1963; Miller et al., 1977; Miller, 1991) have undergone large fluctuations in population size over several decades. Manning (1943), Soper(1944), Ferguson (1989), and Stenton (1991) used fragmentary, secondhand information to suggest similar fluctuations in caribou populations on Baffin Island. Information from Inuit suggests that entire subpopulations on Baffin Island and elsewhere occasionally undertake predictable, periodic shifts in distribution and abundance. This phenomenon has obvious implications for wildlife management decisions because hunting and predation are unlikely to cause such movements. Additionally, caribou subpopulations may simply rotate between ranges, which would have little consequence for overall population abundance; or, entire populations may decline if decreases occur simultaneously among several subpopulations. If the latter occurs, then population fluctuations of Arctic tundra caribou may be cyclical, as suggested by the Baffin Inuit. Unfortunately, no one has assembled firsthand information to detect the temporal and spatial extent of subpopulation fluctuations, and written records and scientific studies of caribou resident on the Canadian Arctic tundra are too scattered to address these questions.

Many successful nonaboriginal explorers of the Arctic have used Inuit knowledge. Hall (1864) was the first nonInuit to record the geographic and historic knowledge of Inuit on southern Baffin Island in 1860. Using the knowledge of several Inuit, Hall (1873) described much of the geography of Baffin Island that remained unseen by non-Inuit until after Hall's death. Arima (1976) and Ferguson and Messier (1997) have also shown the accuracy and precision of Inuit knowledge.

Freeman (1985), Feit (1988), Gunn et al. (1988), and Berkes (1993) have discussed the characteristics that distinguish indigenous ecological knowledge from scientific knowledge. Despite these differences, many parallels exist between the two forms of knowledge. Individual Inuit have mentally recorded empirical data about wildlife distributions, movements, and abundance that could be useful in the management of wildlife populations. The Inuit understanding of ecology is distinct from the scientific understanding partly because of the rationale for its collection: human survival. Although Inuit can recall many years of numerical information (Freeman, 1975), the survival need emphasizes the question "Are there enough?" over "How many are there?" (Unaaluq, 1959, pers. comm. to R. Williamson, pers. comm. 1993). After declines in the abundance of local subpopulations of game animals, the geographic extent of a hunter's firsthand knowledge expands as the hunter searches larger areas. Once survival needs are met, hunters continue to observe population trends and changing ecological conditions accurately, but without numerical quantification. Unlike the hunter, wildlife ecologists numerically quantify selected variables, but because of costs, ecologists usually collect data on relatively few variables within specific geographic areas for short periods. As a result, wildlife ecologists encounter problems when generalizing their findings to broader spatial and temporal scales. Keith and Windberg (1978) overcame this problem by using the observations of registered trappers to assess the spatial synchrony of snowshoe hare (Lepus americanus) fluctuations across Alberta over a 15year period.

Few persons (e.g., Freeman, 1975; Johannes, 1980; Nakashima, 1993) have documented the extensive ecological knowledge of indigenous peoples so that it can be integrated with scientific ecological knowledge. During 1983-95, Ferguson collected Inuit knowledge about caribou on southern Baffin Island over the past 90 years to broaden the historical context for future management of this population. In this paper, we present a composite view of caribou population changes on southern Baffin Island derived from the observations of 43 Inuit elders and active hunters. We then present indices of changes in population abundance derived from Inuit knowledge. Finally, we discuss Inuit knowledge that suggests that fluctuations in the South Baffin caribou population are cyclic, and compare Inuit knowledge with reports by non-Inuit. Repeated inconsistency between nonInuit reports and our compilation of Inuit knowledge could indicate that one or both of the information sources was 
inaccurate, or that we failed to preserve accuracy in our compilation. Ferguson and Messier (1997) presented evidence of the inherent veracity of Inuit knowledge, and concluded that either inaccurate non-Inuit reporting or errors in our compilation of Inuit knowledge would largely account for discrepancies between the two data sources.

\section{METHODS}

Ferguson and Messier (1997) described the general methodology and the roles of Inuit participants and advisors. The research effort was substantial: we spent over 200 hours in interviews, 700-800 person-hours in translating and transcribing interviews, and at least one person-year in data analysis and interpretation. The Hunters and Trappers Associations (HTAs) in Pangnirtung, Iqaluit, Kimmirut, and Cape Dorset (Fig. 1) and other local advisors suggested names of potential informants who, together, could cover the historical range of South Baffin caribou. The temporal coverage was maximized by selecting elders and older active hunters over younger hunters, although some younger hunters provided details about recent caribou distributions. Informants interviewed in Pangnirtung and Kimmirut in 1994 (Table 1) signed consent forms, generally indicating that raw data should be deposited at local community resource centres, that permission for further use of raw data must be obtained from each informant or a named heir, and that their contributions must be acknowledged. Each informant personally owns his information and his initials (Table 1) appear in the text to indicate a personal communication. Most informants were interviewed by a researcher and an interpreter for two to seven hours. Most interviews were tape-recorded, and geographic information was recorded on clear plastic over 1:250 000 or 1:500 000 topographical maps.

\section{Interview Protocol}

During each interview, we developed a biographical map and a detailed individual time line from the informant's recollections of dateable events (Ferguson and Messier, 1997). The informant then described and mapped seasonal and

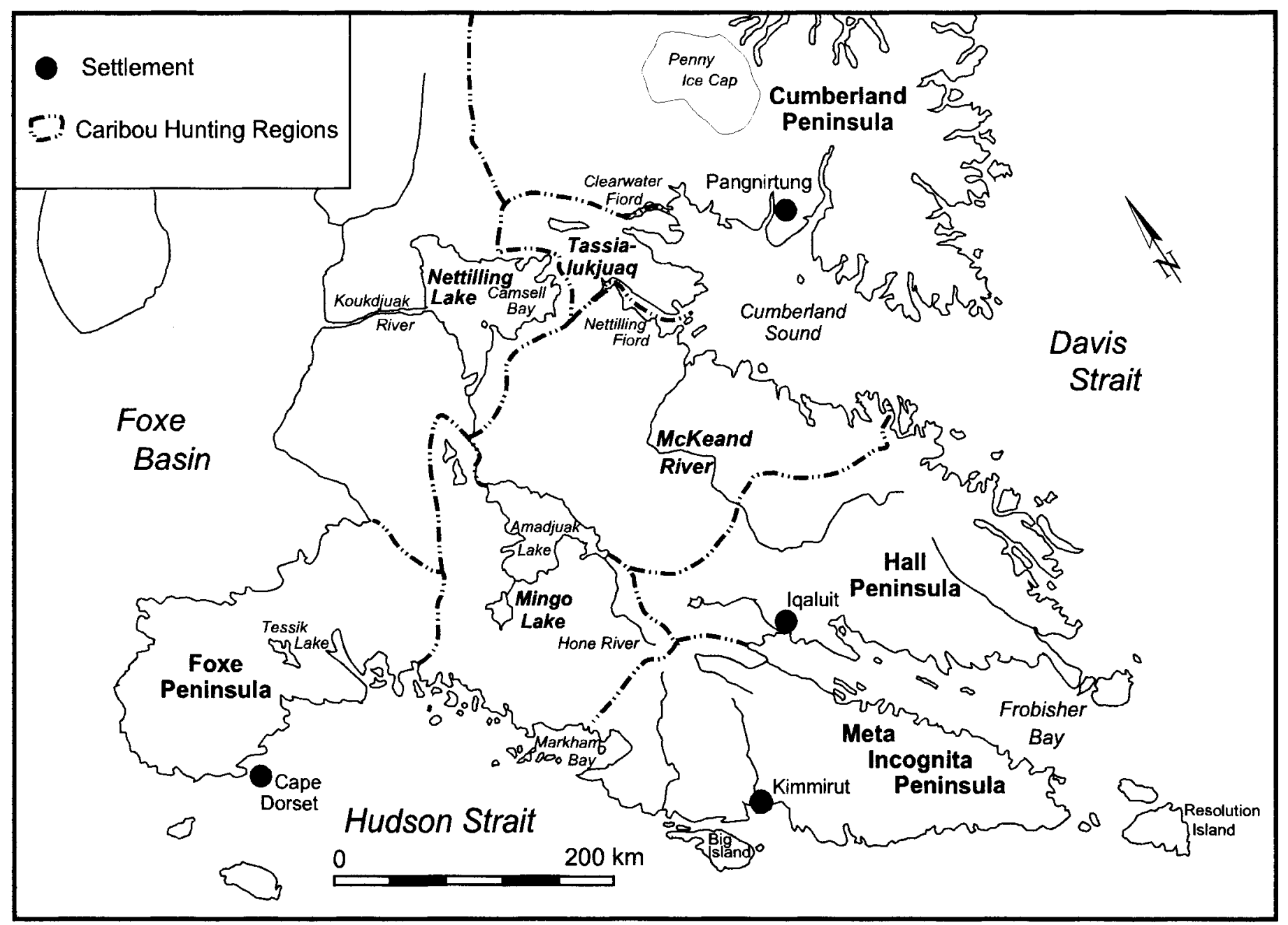

FIG. 1. Caribou hunting regions on southern Baffin Island, Northwest Territories. 
TABLE 1. Inuit informants who provided information about caribou distributions, abundance, and migrations on southern Baffin Island, Northwest Territories.

\begin{tabular}{|c|c|c|c|c|c|}
\hline Informants initials $^{1}$ & Name & Year & Interview location & Interview team ${ }^{2}$ & Type of interview ${ }^{3}$ \\
\hline $\mathrm{AE}$ & Abraham Etungat & 1985 & Cape Dorset & ML, MJ & Complete \\
\hline AN1 & Akeeshoo Nowdluk & 1988 & Allen Island & $\mathrm{MF}$ & Partial \\
\hline \multirow[t]{2}{*}{ AS } & \multirow[t]{2}{*}{ Akaka Saataa } & 1985 & \multirow[t]{2}{*}{ Iqaluit } & PK1 & Complete \\
\hline & & 1994 & & $\mathrm{MF}, \mathrm{AP}$ & Meeting \\
\hline $\mathrm{CA}$ & Charlie Akpalialuk & 1994 & Pangnirtung & $\mathrm{MF}, \mathrm{JK} 2$ & Complete \\
\hline EA & Etuangat Aksayuk & 1990 & Pangnirtung & $\mathrm{MF}, \mathrm{PK} 2$ & Complete \\
\hline EK & Elijah Keenainak & 1994 & Pangnirtung & $\mathrm{MF}, \mathrm{AN} 2$ & Complete \\
\hline EN1 & Enosik Nashalik & 1994 & Pangnirtung & $\mathrm{MF}, \mathrm{AN} 2$ & Complete \\
\hline $\mathrm{EN} 2$ & Equaluk Nungusuituk & 1985 & Cape Dorset & ML, MJ & Complete \\
\hline $\mathrm{EP}$ & Ejeetsiak Peter & 1985 & Cape Dorset & ML, MJ & Complete \\
\hline GU & Geosha Uniuqsaraq & 1994 & Iqaluit & $\mathrm{MF}, \mathrm{AP}$ & Meeting \\
\hline HK & Harry Kilabuk & 1985 & Iqaluit & PK1 & Complete \\
\hline II & Iola Ikkidluak & 1994 & Kimmirut & $\mathrm{MF}, \mathrm{MA}$ & Complete \\
\hline JA & Joe Arlooktoo & 1994 & Kimmirut & $\mathrm{MF}, \mathrm{MA}$ & Complete \\
\hline $\mathrm{JE}$ & Jaco Evic & 1990 & Pangnirtung & $\mathrm{MF}, \mathrm{PK} 2$ & Complete \\
\hline JK1 & Josephie Keenainak & 1994 & Pangnirtung & $\mathrm{MF}, \mathrm{AN} 2$ & Complete \\
\hline $\mathrm{JM}$ & Jamesie Mike & 1994 & Pangnirtung & $\mathrm{MF}, \mathrm{JK} 2$ & Complete \\
\hline JP & Josephie Pudloo & 1994 & Kimmirut & $\mathrm{MF}, \mathrm{MA}$ & Complete \\
\hline JT1 & Joe Tikivik & 1985 & Iqaluit & PK1 & Complete \\
\hline JT2 & John Tongak & 1995 & Pond Inlet & GK, JT3 & Partial \\
\hline JT3 & Joe Tigullaraq & 1995 & Pond Inlet & $\mathrm{MF}$ & Partial \\
\hline KK & Korgak Kilabuk & 1985 & Iqaluit & PK1 & Complete \\
\hline \multirow[t]{2}{*}{ LN1 } & \multirow[t]{2}{*}{ Lucassie Nutaraluk } & 1985 & Iqaluit & PK1 & Complete \\
\hline & & 1994 & & $\mathrm{MF}, \mathrm{AP}$ & Meeting \\
\hline \multirow[t]{2}{*}{ LN2 } & \multirow[t]{2}{*}{ Lucassie Nowdluk } & 1985 & Iqaluit & PK1 & Complete \\
\hline & & 1994 & & $\mathrm{MF}, \mathrm{AP}$ & Meeting \\
\hline MP & Markoosie Peter & 1985 & Iqaluit & PK1 & Complete \\
\hline MS & Mathew Saviajuk & 1995 & Cape Dorset & $\mathrm{MF}$ & Partial \\
\hline \multirow[t]{2}{*}{$\mathrm{NI}$} & \multirow[t]{2}{*}{ Novayuk Ipeelie } & 1985 & Iqaluit & PK1 & Complete \\
\hline & & 1994 & & $\mathrm{MF}, \mathrm{AP}$ & Meeting \\
\hline $\mathrm{OA}$ & Ohituq Ashoona & 1995 & Cape Dorset & $\mathrm{MF}$ & Partial \\
\hline $\mathrm{OP}$ & Osuitsiaq Pudlat & 1985 & Cape Dorset & ML, MJ & Complete \\
\hline \multirow[t]{2}{*}{ OQ } & \multirow[t]{2}{*}{ Okaetok Quaraq } & 1985 & Iqaluit & PK1 & Complete \\
\hline & & 1994 & & $\mathrm{MF}, \mathrm{AP}$ & Meeting \\
\hline PA1 & Pauloosie Angmarlik & 1990 & Pangnirtung & $\mathrm{MF}, \mathrm{PK} 2$ & Complete \\
\hline PA2 & Peteroosie Anilniliak & 1994 & Pangnirtung & $\mathrm{MF}, \mathrm{AN} 2$ & Complete \\
\hline PK1 & Pauloosie Kilabuk & 1994 & Iqaluit & MF & Partial \\
\hline PL & Pauloosie Lyta & 1994 & Kimmirut & $\mathrm{MF}, \mathrm{MA}$ & Complete \\
\hline PN1 & Pauloosie Nowyook & 1994 & Pangnirtung & $\mathrm{MF}, \mathrm{JK} 2$ & Complete \\
\hline \multirow[t]{2}{*}{$\mathrm{PN} 2$} & \multirow[t]{2}{*}{ Pudloo Nowdluk } & 1985 & Iqaluit & PK1 & Complete \\
\hline & & 1994 & & $\mathrm{MF}, \mathrm{AP}$ & Meeting \\
\hline PP & Paulassie Pootoogook & 1985 & Cape Dorset & ML, MJ & Complete \\
\hline \multirow{2}{*}{ SA1 } & \multirow[t]{2}{*}{ Simonie Alainga } & 1983 & Iqaluit & $\mathrm{MF}, \mathrm{GA}$ & Complete \\
\hline & & 1994 & & $\mathrm{MF}, \mathrm{AP}$ & Meeting \\
\hline SA2 & Sandy Akavak & 1994 & Kimmirut & $\mathrm{MF}, \mathrm{MA}$ & Complete \\
\hline SK & Simeonie Keenainak & 1995 & Pangnirtung & $\mathrm{MF}$ & Partial \\
\hline SQ & Simionie Quppapik & 1985 & Cape Dorset & ML, MJ & Complete \\
\hline SR & Sakiassie Ragee & 1985 & Cape Dorset & ML, MJ & Complete \\
\hline SS & Sagiatuk Sagiatuk & 1985 & Cape Dorset & ML, MJ & Complete \\
\hline $\mathrm{TM}$ & Towkie Maniapik & 1990 & Pangnirtung & $\mathrm{MF}, \mathrm{PK} 2$ & Complete \\
\hline
\end{tabular}

${ }^{1}$ Initials used in text to indicate personal communications.

${ }^{2}$ Persons who interviewed the informants were: Aiju Peter (AP), Amie Nashalik (AN2), Goo Arlooktoo (GA), George Koonoo (GK), Jonah Kilabuk (JK2), Joe Tigullaraq (JT3), Mathew Akavak (MA), Martha Jaw (MJ), Michael Ferguson (MF), Michel Labine (ML), Pauloosie Kilabuk (PK1) and Peter Kilabuk (PK2).

${ }^{3}$ Complete interviews of individual informants were conducted to collect information about the whole life of the informants. Partial interviews and one meeting were conducted to fill specific information gaps.

interannual changes in caribou distributions and relative abundance, largely on the basis of his own observations of caribou (i.e., personal information) and observations of his parents and grandparents (i.e., parental information). Starting with his first memory of caribou, the informant was asked to recall his observations while he lived at each of his homes in sequential order. We will report general circumstances in which the locations of Inuit residences affected their knowledge of caribou distributions, but we did not obtain permission to publish these locations.

For each observation of caribou, we elicited information about the location, timing (i.e., month or season), number of caribou or tracks, sex/age class of caribou, and direction of travel of the caribou. Informants were asked to distinguish 
areas with caribou of sex/age classes that were being hunted, areas with non-target classes of caribou, areas with no caribou, and areas that were not hunted because of the terrain or other conditions. Distributions of mature males (bulls) and mature females (cows) with calves were emphasized because they exhibited the greatest geographic separation. Informants were asked to draw the routes and hunting areas that they used while hunting caribou.

When caribou were scarce, informants usually recalled precise numbers of animals that they and other hunters had harvested or the total number seen, or both. When the abundance of caribou was sufficient to meet their needs, informants usually did not know the number seen. As well, terms describing abundance (e.g., "few," "lots") depend on the informant's previous experience; e.g., five caribou may be "lots" if a hunter has not seen a caribou for several years, but "few" after he has seen hundreds of caribou daily. Consequently, the informant was asked to directly compare caribou abundance to that seen previously and later in his life within the same area and in other areas (e.g., "more," "less").

Seasonal migrations resulted in changes in caribou abundance in a specific area that lasted for several weeks or months and occurred annually for several years or decades. Most informants were extremely disciplined and specific in reporting only the actual routes and directions of travel that they observed, avoiding speculation. Informants sometimes speculated in response to leading questions in which the interviewer suggested the ultimate destination (Ferguson and Messier, 1997). We eliminated such speculative responses from the analysis.

\section{Data Analysis and Presentation}

English transcripts of each interview were examined in detail to eliminate answers that may have been affected by inappropriate questions, secondhand information, and other factors (Ferguson and Messier, 1997). A minimum acceptable precision of $\pm 3 \mathrm{yr}$ was set arbitrarily for temporal data. A composite illustration of changes in caribou distribution and abundance was developed by plotting the observations of all informants on clear plastic over a 1:500 000 map for each decade. Major hunting regions became evident, and each had relatively distinct historical patterns of caribou population changes and hunting by Inuit. Written synopses of informants' observations were merged in chronological order for each major caribou hunting region (Fig. 1). For presentation purposes, the composite overlays were redrawn to illustrate caribou distributions during the first four years of each decade, beginning with 1910-13. The four-year period was chosen to coincide with our accepted temporal precision, to allow sufficient time to illustrate inter-decade changes, and to portray generalized population distributions (as opposed to unusual distributions occurring in a specific year).

Caribou distributions were analyzed for: "summer" (i.e., June to August), "autumn" (i.e., September to early December), "winter" (i.e., mid-December to mid-March) and "spring" (i.e., late March to May). Figures 2 to 5 show summer and winter distributions for the even-numbered decades from 1920 to 1980 . The distributions for 1990-93 are given in Figure 6, since major changes have occurred since the 1980s.

After comparing statements of all informants about caribou abundance relative to other areas, years and seasons, we assigned a caribou abundance code to each hunting area for each season during the first four years of each decade (e.g., spring 1910-13). Although we used descriptions that directly compared spatial and temporal differences in caribou abundance, each category usually corresponded to typical Inuit descriptions of abundance relative to the needs of caribou hunters (Table 2). Descriptions based on need apply mainly to the 1950s and previous decades, before most of the informants moved into the communities. In discussing these abundance categories with Inuit, it became evident that the differences between the categories were probably exponential rather than arithmetic. Thus, a simple numerical ranking of the six categories (e.g., 0-5) would misrepresent changes in abundance over time. To develop an appropriate scale for the relative change from one category to the next, we compared Inuit descriptions of abundance in specific areas with densities estimated during aerial surveys over much of southern Baffin Island during the 1980s and 1990s (Ferguson, unpubl. data). The abundances described by Inuit were generally consistent with densities estimated from the surveys (Table 2). Caughley (1977) recognized that persons thoroughly knowledgeable about an area and its wildlife can make realistic "guesses" about the abundance of animals. He pointed out that the value of a given guess depended on the length of time the person was in the area, the indicators used to derive the guess and the person's experience. Caughley also suggested that such guesses are useful checks of the accuracy of survey estimates. We reversed the process by using aerial survey results to develop a numerical scale for Inuit descriptions of caribou abundance. The combination of Inuit knowledge and aerial survey data yields the only assessment of long-term population trends possible for this population. Overall abundance indices were obtained by combining the applicable assumed densities from Table 2 and the amount of area known by the informants. Specific terminology was used consistently throughout this paper (Table 3 ).

\section{Comparisons with Non-Inuit Reports}

The detail of observations preserved in Inuit oral traditions and corroborated by written records is remarkable (Ferguson and Messier, 1997). As with Inuit knowledge, we examined the context of each historical report written by non-Inuit for an equitable comparison of the two types of information. For example, Soper (1944) did not see any caribou near Kimmirut during 1930-31, but neglected to report that from autumn 1930 to June 1931, he did not travel extensively because of an injury (Soper, 1981). The lack of firsthand observations in non-Inuit reports often reflects limited opportunities for observing wildlife rather than limited distributions of wildlife.

Relative quantification (e.g., "plenty") is also problematic. RCMP reports from Pangnirtung confirmed informant 
TABLE 2. Caribou abundance on southern Baffin Island, Northwest Territories, as described by Inuit caribou hunters relative to their needs, ${ }^{1}$ and corresponding approximate caribou densities determined from aerial surveys during the 1980s and 1990s.

\begin{tabular}{clc}
\hline \hline \multicolumn{2}{c}{ Abundance of caribou } \\
\hline Map code & Abundance relative to needs & $\begin{array}{c}\text { Aerial survey density } \\
\left(\text { caribou } / \mathrm{km}^{2}\right)\end{array}$ \\
\hline 0 & No sign of caribou. $^{2}$ & 0.0 \\
1 & Only caribou tracks seen. $^{2}$ & 0.008 \\
2 & Not enough to meet their needs. $_{3}$ & 0.04 \\
4 & Enough to meet their needs. $^{2}$ & 0.2 \\
5 & Plenty of choice to meet their needs. $^{3}$ & 1.0 \\
\hline \hline
\end{tabular}

${ }^{1}$ Abundance codes were assigned on the basis of direct comparisons in the relative abundance of caribou in different years, seasons, and areas, known to each informant. Abundance relative to needs was applicable mainly to years before most of the informants moved into communities.

${ }^{2}$ Obviously there were not enough caribou to meet their needs.

${ }^{3}$ Obviously there was plenty of choice, but this also represented concern about the ability of the habitat to sustain such abundance of caribou over the long term

evidence that densities had decreased in the late 1920s. However, reports by two new RCMP officers in 1930-32 reported "plenty" of caribou near Pangnirtung and northern Cumberland Sound. We gave greater weight to descriptions of relative abundance by older Inuit because of their broader temporal context (Ferguson and Messier, 1997). We also viewed temporal and spatial frames of reference critically before using written reports.

Many reports about caribou written by non-Inuit are actually secondhand reports from Inuit, but the writers may not have understood Inuktitut and Inuit culture adequately to report Inuit knowledge accurately. For example, Hantzsch (1977) did not display the same understanding of Inuit culture that Hall (1864) and Boas (1974) had. Hantzsch was annoyed when the Inuit delayed his expedition, especially on clear days suitable for travel and for drying caribou skins. He reported the number of caribou harvested for meat, but the skins of these caribou would have been insufficient to provide winter clothing for the entire party. When Inuit observations are reported by non-Inuit, the linguistic and cultural contexts often become difficult to judge.

The assumptions of each author in extrapolations made from actual observations were also examined. In 1931, Soper (1944:249) observed caribou trails on Meta Incognita Peninsula that "appeared remarkably fresh," but had not been used "for a considerable period" because some parts of the trails were overgrown by $10-12$ yr old willows (Salix spp.). However, snow often protects vegetation during spring caribou migrations, and willows often remain lush in low parts of caribou trails even during summer migrations (Ferguson, unpubl. data). In such situations, we accepted firsthand and parental observation of Inuit information over non-Inuit inferences or speculation.
TABLE 3. Definitions of terminology in this paper.

\begin{tabular}{|c|c|}
\hline Term & Definition \\
\hline Appearance & $\begin{array}{l}\text { Rapid occupation of an area through immigration } \\
\text { (i.e., usually during } 1-5 \mathrm{yr} \text { ). }\end{array}$ \\
\hline Disappearance, decrease & $\begin{array}{l}\text { Reduced population abundance over a few years } \\
\text { (i.e., usually less than 10), possibly due to } \\
\text { emigration, reduced survival, and/or low calf } \\
\text { production. }\end{array}$ \\
\hline Emigration, immigration & $\begin{array}{l}\text { Movements producing a large change in population } \\
\text { abundance between years. Conclusive evidence of } \\
\text { emigration was difficult to obtain. }\end{array}$ \\
\hline Expansion, increase & $\begin{array}{l}\text { Increases in geographic distribution and population } \\
\text { abundance, respectively. }\end{array}$ \\
\hline Migration & $\begin{array}{l}\text { Seasonal movements of caribou reported by the } \\
\text { informants. }\end{array}$ \\
\hline Range expansion & $\begin{array}{l}\text { An overall increase in the size of an area occupied } \\
\text { seasonally by caribou. }\end{array}$ \\
\hline Range drift & $\begin{array}{l}\text { An expansion of a seasonal area in one direction } \\
\text { and a concomitant shrinkage in another, resulting } \\
\text { in no or little net change in area occupied. }\end{array}$ \\
\hline Range shift & $\begin{array}{l}\text { The almost complete abandonment of one seasonal } \\
\text { area and the concomitant occupation of another } \\
\text { area(s) that will be used for several years thereafter. }\end{array}$ \\
\hline Range volatility & $\begin{array}{l}\text { Frequent, unpredictable interannual changes in } \\
\text { the seasonal distribution of caribou. }\end{array}$ \\
\hline Special areas & $\begin{array}{l}\text { Areas that the informants" elders had described as } \\
\text { places that would have caribou "when all other } \\
\text { areas have no caribou." }\end{array}$ \\
\hline
\end{tabular}

\section{RESULTS}

To illustrate the accuracy and precision of the informants' recollections, we include below a detailed description of their compiled knowledge for the Foxe Peninsula caribou hunting region. Shorter synopses are given for the other hunting regions, but detailed compilations are available from Ferguson upon request. Place names are presented on Figure 1.

\section{Foxe Peninsula Hunting Region}

By c. 1900 (EN2, NI) caribou were common throughout most of Foxe Peninsula in both summer and winter, and they had inhabited nearby islands in Hudson Strait by c. 1911 (EN2, LN1, NI, SQ, Fig. 1). This range extended east to the Mingo Lake region (SQ). Caribou began to disappear from coastal areas in c. 1918 (SQ, Fig. 2), and most caribou disappeared from Foxe Peninsula after c. 1923 (EN2, LN1, NI, SQ, Fig. 7A). All informants except OP, PP, and SR reported that caribou could not be found on Foxe Peninsula from c. 1926 until the late 1950s (AE, EN2, II, JA, LN1, NI, SQ). From c. 1926 to c. 1942, OP, PP, SR or their parents found some caribou during two to four winters each. Caribou abundance was very low: none were found in some years, and a maximum of three caribou were taken during three weeks of hunting in other years (PP, Fig. 3). OP and SR knew of no caribou taken on the peninsula after c. 1935, but PP reported that his father found a few caribou in some winters until c. 1942. 


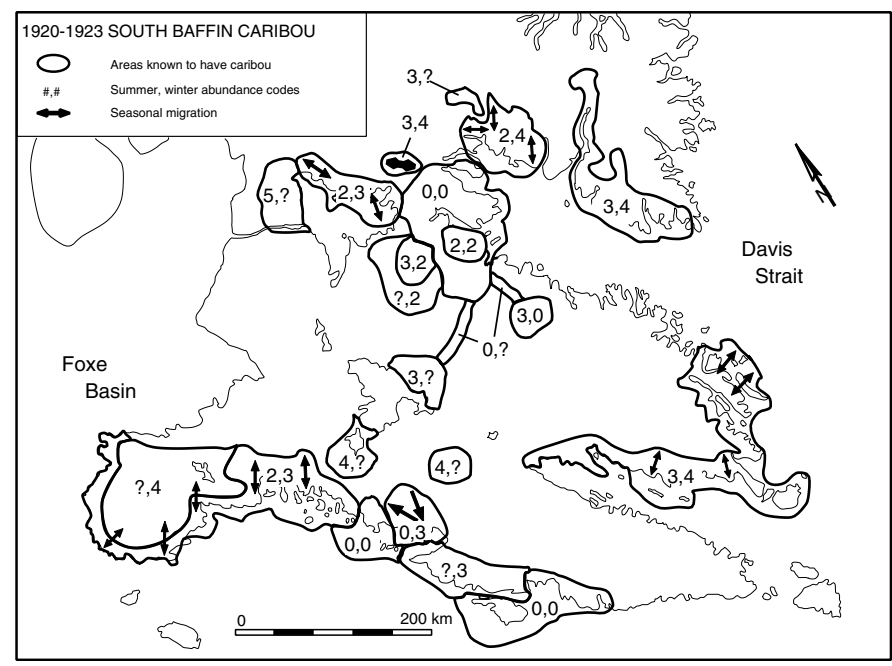

FIG. 2. Distributions, abundance (Table 2) and seasonal migrations of caribou on southern Baffin Island during 1920-23, based on Inuit knowledge.

By the late 1920s, several families from Foxe Peninsula were living for months or years near Mingo, Amadjuak, and/ or Nettilling Lakes to hunt caribou and trap foxes (AE, LN1, NI, PP, SQ). By the early 1930s, Inuit near Cape Dorset were obtaining imported caribou skins and sinew at the Hudson's Bay Company (HBC) post (OP). Until 1944, Inuit living on Foxe Peninsula received caribou skins and meat from family members living at Nettilling Lake (PP). During 1946-50, none of the informants from Cape Dorset hunted caribou near Amadjuak and Nettilling Lakes, although caribou had not yet returned to Foxe Peninsula. Trading posts in Cape Dorset discouraged harvesting of caribou near these lakes at the request of the Deputy Commissioner of the Northwest Territories (Ferguson and Messier, 1997).

From the late 1920s through the early 1950s, informants travelled extensively on Foxe Peninsula in winter and spring and along the coast in summer, despite the lack of caribou. If caribou had occupied the peninsula during this period, hunters would have detected some sign of them. The return of caribou to northeastern Foxe Peninsula began in c. 1955 when somebody reported tracks of two caribou (SR). AE first saw caribou in that area in winter c. 1957. Then in winter c. 1958, caribou were seen farther west near Tessik Lake (SR, SS).

In the early 1960s, caribou increased (Fig. 7A) from Tessik Lake east to the Mingo Lake region and probably beyond (AE, II, Fig. 4). As caribou immigrated onto Foxe Peninsula in the late 1950s and early 1960s, cows and calves arrived each September-October, followed by bulls (AE). After c. 1960, mainly bulls were seen along the coast during winter, while cows and calves were usually $15 \mathrm{~km}$ or more inland near lakes (EP, SR, SS). Tessik Lake became the main winter hunting area of most informants during the 1960s. By the mid-1960s, bulls were remaining on the coast of eastern Foxe Peninsula during summer, and during the late 1960s some cows and calves were also seen on this coast in summer (SS).

During winter in the early 1970s, caribou expanded westward past Tessik Lake (SR, SS). Their summer range in that period extended from south of Tessik Lake east to the Mingo

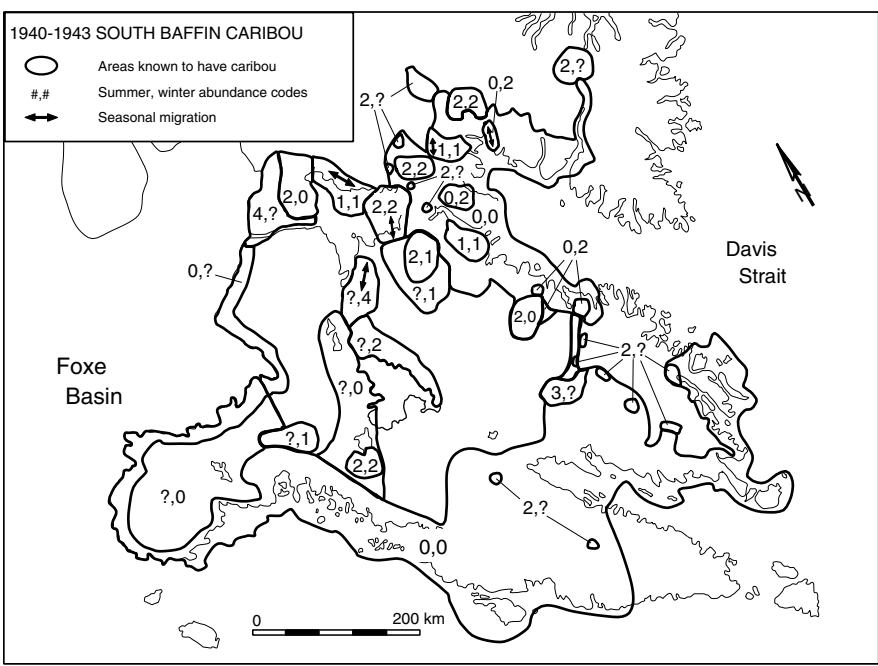

FIG. 3. Distributions, abundance (Table 2) and seasonal migrations of caribou on southern Baffin Island during 1940-43, based on Inuit knowledge.

Lake region (SR, SS). Besides expanding their winter and summer ranges, caribou increased in abundance from the 1960s into the 1980s (EN2, EP, OA, SR, SS, Fig. 7A). By c. 1980, caribou occupied western Foxe Peninsula in winter, spring, and summer (OA, SR, Fig. 5). Caribou continued to occupy the coastal area south of Tessik Lake (EP, MS) and expanded to the south and east along the coast by winter c. 1983 (EN2). In the 1980s, caribou continued to winter on eastern Foxe Peninsula (EP, MS). However, within that area, caribou densities decreased after winter c. 1983 (EP); the caribou range was drifting rather than expanding during the mid-1980s. Also during the 1980s, bulls moved onto nearby islands in Hudson Strait during winter and remained along the coast year-round (OA), while cows were on the coast mainly during winter (EN2, OA).

Seasonal migrations on Foxe Peninsula during the early 1900s (LN1, NI, Fig. 2) were similar to those during c. 197085 (Fig. 5), caribou abundance being highest during winter (EP, SS). In the 1970s, cows and some bulls migrated inland during May (EN2, EP, LN1, SS, SR). During summer, mainly males were harvested near the coast (NI). By c. 1980, most cows migrated inland late in May and returned to the coast with newborn calves in early August, remaining until the next spring (OA). Starting in c. 1983, some cows remained along the coast year-round, so EP believed that females calved close to Cape Dorset. None of the informants had observed calving females, although secondhand information suggested that a large calving area had been seen by other hunters on western Foxe Peninsula in the early 1980s (EN2). During SeptemberOctober, bulls migrated inland to find cows (EP). There was no discrete rutting area, because caribou moved extensively throughout the peninsula during October-November (EP).

In 1985, EP and PP predicted that caribou would soon leave Foxe Peninsula because of the above changes in distribution and migrations and the past predictions of their elders. A sudden, major decrease occurred on Foxe Peninsula between spring and autumn in 1989 or 1990, after which few caribou wintered on the peninsula (MS, OA, Figs. 5, 6, 7A). 


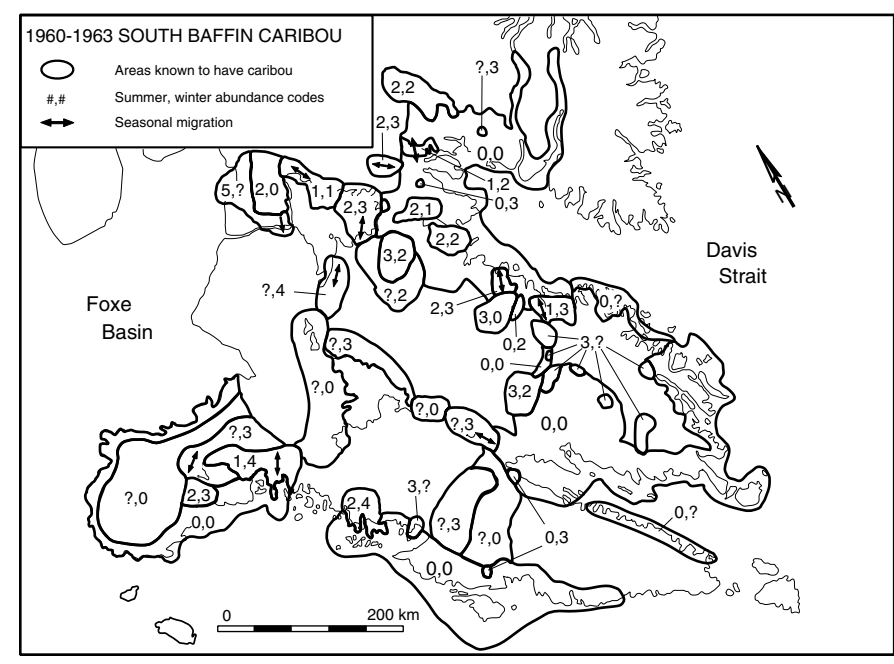

FIG. 4. Distributions, abundance (Table 2) and seasonal migrations of caribou on southern Baffin Island during 1960-63, based on Inuit knowledge.

Since then, caribou have been seen in groups of two to three and never more than ten (JT3, OA). OA has seen only three or four caribou per day of hunting in winter since c. 1990. None of the informants reported a major increase in natural mortality, although a few caribou were found dead at the bottoms of cliffs. By 1994, caribou were so rare on Foxe Peninsula that friends in Iqaluit regularly sent meat to Cape Dorset residents, and some Cape Dorset hunters had hunted caribou on Southampton Island, about $250 \mathrm{~km}$ west of Cape Dorset (MS).

\section{Mingo Lake Hunting Region}

Informants did not hunt regularly near Hone River because of its distance from camps on Frobisher Bay and Hudson Strait. Nevertheless, informants knew it as a special area where caribou could be found if unavailable elsewhere. During summer c. 1919-24, caribou were found near the headwaters of the Hone River (SA2, Fig. 2). Some Kimmirut hunters got caribou near the Hone River in summer throughout the 1930s (JP, SA2). From c. 1942 to c. 1953 during winter, a few caribou or at least tracks were seen near the river (AS, HK, JA, JP, PL, SA1). Subsequently, informants rarely hunted near the Hone River, as caribou began appearing nearer to the coast.

Mainly cows with calves wintered along the coast of this region from c. 1917 (or before) until c. 1928 (SQ, Fig. 2). Many cows and newborn calves summered around Mingo Lake and southwestern Amadjuak Lake during c. 1917-22 (AE, SQ), but caribou abundance was low by summer c. 1928-32 (EN2, Fig. 7B). During winter in the 1930s, 1940s (Fig. 3) and early 1950s, caribou abundance was very low throughout this region (AE, EN2, JT2, LN1, NI, SQ, SR). No sign of caribou was reported west of Amadjuak Lake during winter and spring. From c. 1939 until c. 1956, a few caribou were occasionally seen south of Mingo Lake in summer and winter (EP, II, JA, PL, SS, Fig. 3). Until c. 1956, each hunting party usually could get no more than two

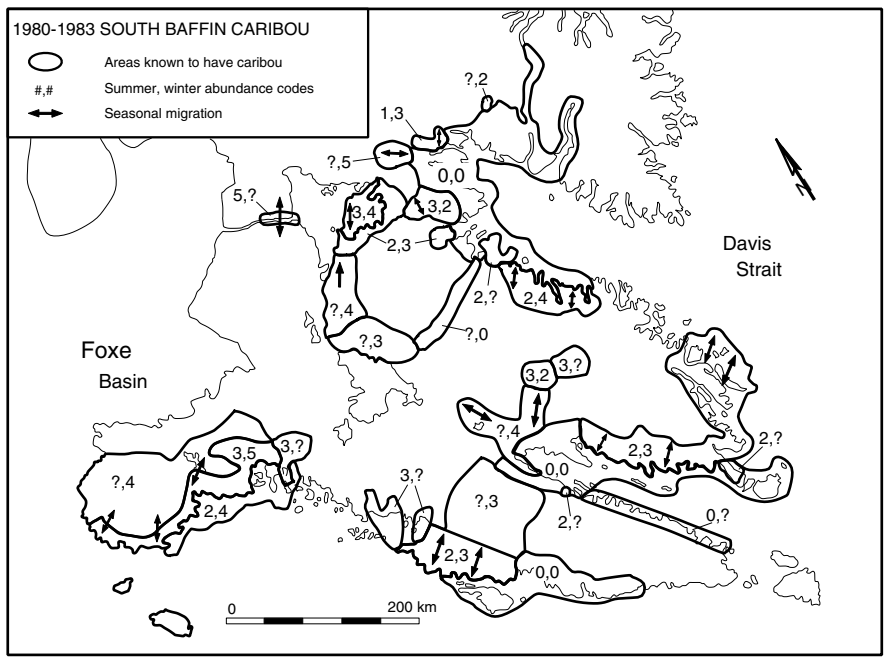

FIG. 5. Distributions, abundance (Table 2) and seasonal migrations of caribou on southern Baffin Island during 1980-83, based on Inuit knowledge.

caribou in winter (II, PL, SS). Inuit living in this region during c. 1944-49 were often hungry and cold because of insufficient caribou and other wildlife (II). In c. 1956, caribou began returning to the coast in winter (EP, SS), but subsequent observations are limited because most residents moved to Cape Dorset or Kimmirut by c. 1959 as requested by the Royal Canadian Mounted Police (RCMP) (SQ). By c. 1960, caribou remained along the eastern coast of the region during summer, but abundance was higher during winter (II, Figs. 4, 7B). During summer c. 1979-81, caribou were seen along the coast and on smaller islands (JP, Fig. 5).

\section{Meta Incognita Peninsula Hunting Region}

Caribou apparently occurred along the entire coast of Meta Incognita Peninsula in the early 1900s (JP, LN2, PL, SA2). By the early 1920s, caribou had disappeared from the coast of Hudson Strait southeast of Kimmirut and abundance had decreased (PL, Fig. 2, 7C), but some caribou continued to winter along the northwest coast until c. 1930 (JP, SA2). Informants rarely travelled among the interior plateaux and mountains of Meta Incognita Peninsula before c. 1939 (AS, JA, JP, PL, SA2), so caribou may have remained there throughout the 1930s (JA). From c. 1939 to c. 1950, groups of 2-4 caribou were occasionally found inland during summer, if any caribou were seen at all (AS, KK, PL, Fig. 3). In Kimmirut, caribou meat was extremely rare from c. 1946 to c. 1951 (JP, SA2).

During c. 1950-52, tracks of one caribou were seen among the mountains (AS, JA, NI, PL). Then, during winter from c. 1953 to c. 1956 , signs of caribou increased: up to 10 caribou were seen occasionally (JP, SA1, SA2). In c. 1958, SA2 noticed a marked increase in caribou abundance; he saw about 21 caribou during one hunt and more during another. More Kimmirut hunters started actively hunting caribou, taking 20-25 caribou that winter (SA2). The caribou population expanded and increased toward the southwest during the winters of c. 1959-61 (JP, SA2, Fig. 4). After c. 1958, 
SA2 saw too many caribou to estimate the numbers that he saw or harvested.

During winter c. 1963, the caribou range expanded again towards the coast, but most caribou remained at least $50 \mathrm{~km}$ north of Kimmirut (II, SA2). By the late 1960s, about 10 caribou were harvested annually for every five hunters in Kimmirut (JA). By the mid-1970s, the caribou had expanded their winter range to within $20 \mathrm{~km}$ of Kimmirut (JA, JP, SA2). Iqaluit hunters occasionally saw caribou near the northwest coast of Frobisher Bay (LN1, MP, NI).

During the late 1970s and early 1980s, caribou expanded their spring range along the coast about $70 \mathrm{~km}$ southeast of Kimmirut (SA2, Fig. 5). After c. 1978, caribou were seen near Markham Bay during summer, winter, and spring (JA, JP, SA2). All sex/age classes of caribou were seen during winter and spring (SA2). In May, cows migrated inland, but they returned to areas near the coast in July (SA2). In c. 1980, caribou expanded their range onto islands in Markham Bay (JP).

In winter c. 1989, the caribou range expanded and abundance increased suddenly and dramatically (JP, II, SA2, Figs. 6, 7C). Since the c. 1989 increase, some cows have still migrated inland into the mountains in spring, but the majority have migrated to the northwest in spring, not returning until October-November (JP, SA2). In c. 1991 or 1992, bulls appeared on Big Island and other islands in Hudson Strait (JA, II, SA2). In spring c. 1993 cows also began to use small islands up to $25 \mathrm{~km}$ off Baffin Island (II, JA). Bulls that spend winter, spring, and summer on Big Island swim back to the peninsula in September, apparently to meet females returning from the northwest (II).

In winter 1993-94, caribou decreased near Kimmirut (SA2). However, in spring c. 1994, more caribou than in previous years migrated northwest past Kimmirut, coming from southeastern Meta Incognita Peninsula (SA2). The northwestward migration past Kimmirut occurred in May, instead of April (SA2). The process of drifting winter range apparently began on Meta Incognita Peninsula only four years after the mass immigration of caribou, probably from Foxe Peninsula. In 1994, JA predicted that within 10 years caribou would leave Meta Incognita Peninsula.

\section{Hall Peninsula Hunting Region}

From c. 1900-1920, caribou occurred along most of the coast of Hall Peninsula and on islands in Frobisher Bay (HK, LN2, PN2, OQ, Fig. 2) until they largely disappeared after c. 1922 (PN2, Fig. 7D). Caribou were so common that hunters got enough caribou while hunting other game (e.g., arctic hare, Lepus arcticus) (PN2). Caribou remained at the heads of fiords on western Hall Peninsula until summer c. 1928 (HK, KK, OQ). Only PN2 reported any knowledge of caribou along the coast of the peninsula until the late 1950s. During the summers of c. 1935-59, he and his father usually got a few caribou in a special area on eastern Hall Peninsula (Figs. 3, 4), but in some years they found none.

In summer from c. 1929 to the mid-1960s (Figs. 3, 4), caribou occurred on the interior of Hall Peninsula in a few

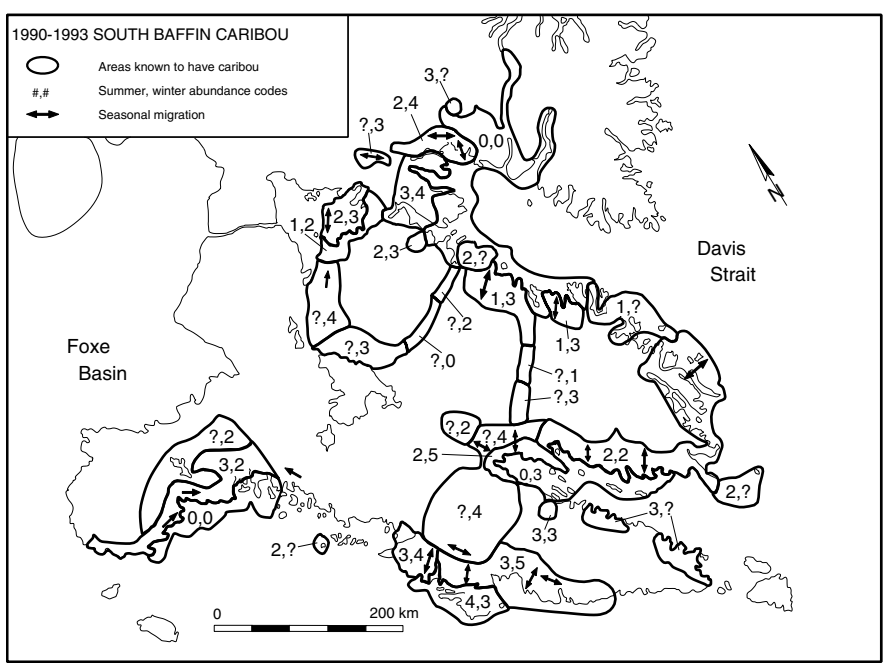

FIG. 6. Distributions, abundance (Table 2) and seasonal migrations of caribou on southern Baffin Island during 1990-93, based on Inuit knowledge.

special caribou areas (HK, KK, LN2, NI, OQ, PN2, SA1). $\mathrm{HK}$ and PN1 found caribou near the upper McKeand River in most summers, but each family usually got only 4-7 caribou each summer. In the 1940s, caribou expanded and increased slightly east of the McKeand River, but abundance remained low (HK, PN1, SA1, Fig. 7D). Some families were starving in some summers while hunting caribou during the 1930s and 1940s (KK, PN1, PN2). Signs of caribou were seen near the McKeand River only in winter and spring c. 1944, c. 1947, and c. 1950 (AS, EA, LN1, NI, SA1). Caribou gradually expanded their winter range from the McKeand River toward Frobisher Bay from c. 1957 until c. 1985 (JT1, MP, Figs. 4, 5, 7D). After caribou appeared along the coast of Hall Peninsula in the 1960 s, hunters rarely hunted the interior, so there was little knowledge of caribou on the plateau after c. 1965.

Beginning in c. 1956, small isolated groups of caribou were seen occasionally near the west coast of Hall Peninsula (JT1, OQ, SA1, LN2), but they did not appear every winter until after c. 1965 (AS, HK, JT1, NI, SA1). Subsequently, caribou increased and expanded gradually around the coast of Hall Peninsula until c. 1990 (KK, MP, NI, OQ, SA1, Figs. 5-6). From c. 1974 to c. 1984, caribou expanded through the mountains of eastern Hall Peninsula and onto islands east of the peninsula and in southern Frobisher Bay (GU, JM, KK, LN2, PK1, PN2, SA1, SA2, SK, Fig. 5). Then in the early 1990s, caribou abundance decreased on islands along eastern Hall Peninsula (Fig. 6). By winter c. 1993, caribou abundance on western Hall Peninsula had decreased to less than during the 1980s, and caribou started to feed on very steep terrain (GU).

Caribou were relatively numerous around northern Frobisher Bay during c. 1900-26 (Fig. 2), but by the early 1930s they were rare (PN2). Caribou first re-appeared about $50 \mathrm{~km}$ north of the bay during c. 1947-49, and were usually seen in groups of only $1-2$ caribou during the winter in the early 1950s (AS, HK, JA, JT1, KK, LN1, SA1). During c. 1956-59, some caribou wintered within 

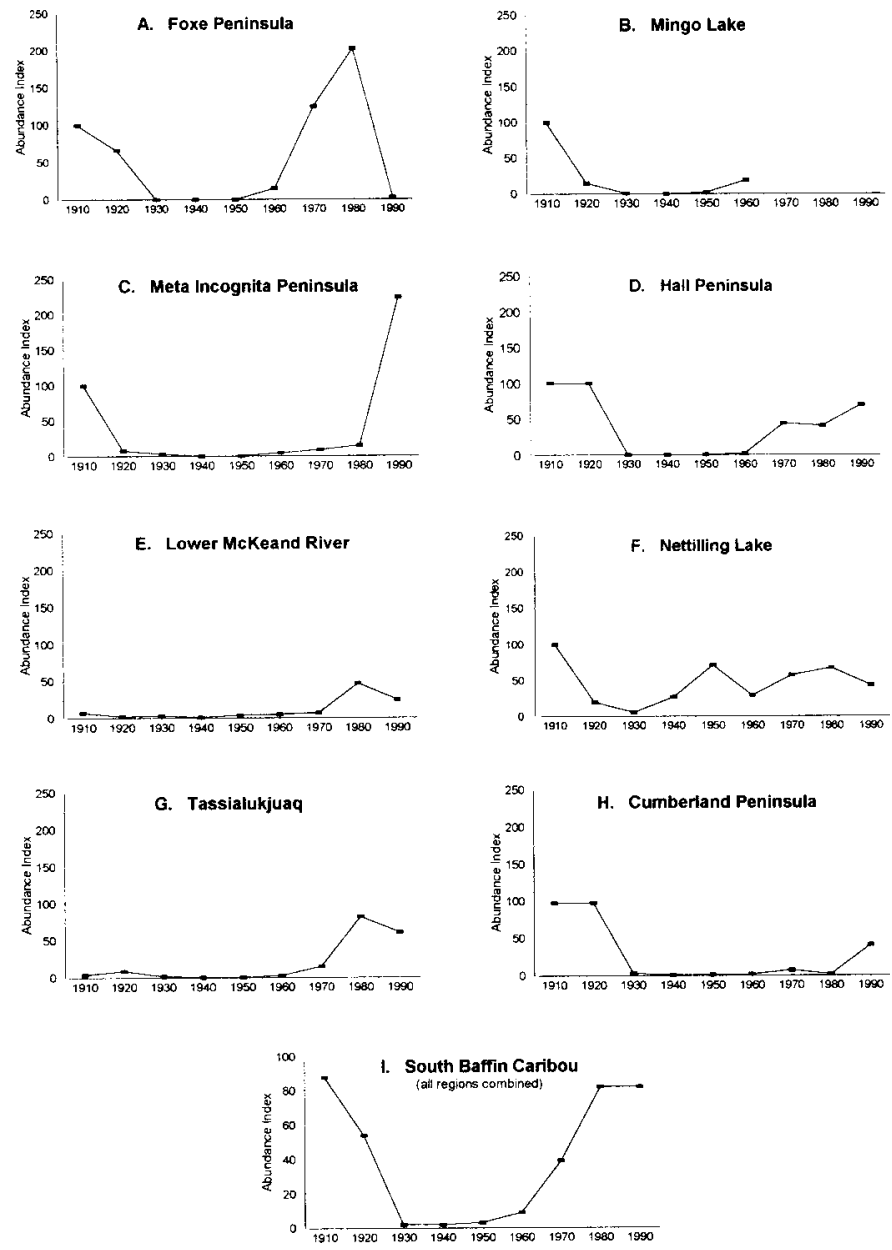

FIG. 7. Relative abundance of caribou within major caribou hunting regions and in all regions on southern Baffin Island during winter, 1910-93.

about $20 \mathrm{~km}$ of the bay (LN1, SA1), but then retreated farther inland until c. 1966 (AS, JT1, LN1, MP, SA1, Fig. 4). Caribou were more common near Amadjuak Lake from the 1930s until the 1960s (LN1, Figs. 3-4). In winter during the 1960s and 1970s, the area about $50 \mathrm{~km}$ northwest of Frobisher Bay became the main Iqaluit hunting area (AS, SA1), but some Inuit hunted near the McKeand River to the northeast (JT1, LN2, Figs. 4-5). During winter in the mid-1970s, caribou were about $25 \mathrm{~km}$ inland (SA2), and expanded their range to the coast of Frobisher Bay by c. 1980 (JT1, LN1, PK1, SA1, Fig. 5).

By the mid-1980s, the winter range of caribou near northern Frobisher Bay was drifting south toward the coast as caribou abundance declined farther inland (PK1, Fig. 6). In winter c. 1989, caribou drifted southeast toward Hall Peninsula (GU, SA1). In the early 1990s, the winter range extended only $35 \mathrm{~km}$ north of Frobisher Bay, and caribou began using islands in the northern part of the bay (LN2, PK1), while caribou abundance was decreasing on the west coast of Hall Peninsula. On the basis of changes in recent distributions of caribou seen by 1985, PN2 predicted that "maybe there will be no caribou like my father said."

\section{McKeand River Hunting Region}

During the 1930s, no caribou were seen along the western coast of Cumberland Sound, except for a few during winter in one small valley (PN1). This area expanded slightly after c. 1939, and caribou were found in two other areas in c. 1941 (Fig. 3). In the early 1950s, abundance increased slightly (PN1). In winter c. 1955, caribou increased and expanded their range into other areas along western Cumberland Sound (CA, PN1, Fig. 4). During winter after c. 1964, caribou occupied most of the coast of western Cumberland Sound (CA, PN1, Fig. 5). Caribou abundance increased in all seasons until the late 1970s, but started to decline during the mid-1980s (JK1, PN1, Fig. 6).

During summer and winter, caribou occurred on the plateau north of the McKeand River from c. 1921 (or before) until the early 1970s (EN1, PA2, Figs. 2-4). During summer, caribou abundance was always lower on this plateau than northwest of Nettilling Lake, and in winter it was even lower (EN1, EN2, PA2). During the 1930s and 1940s, abundance north of the McKeand River was highly variable; no caribou were found in some years (EN1, NI). In c. 1974, caribou increased west of the mouth of Nettilling Fiord (EN1), near areas where TM occasionally saw caribou during c. 1932-62 (Figs. 3, 4). Subsequently, no informant had hunted inland on the plateau during summer. A few caribou were seen in winter during the late 1980s and early 1990s (JE, SK).

Caribou occurred east of Amadjuak Lake in summer c. 1920 , but there were fewer than northwest of Nettilling Lake (EA, Fig. 2). Caribou abundance declined during the late 1920s, 1930s, and 1940s, but hunters usually got a few caribou within the special caribou area near Amadjuak Lake (EN2, EP, LN1, SA1, Figs. 3, 4). No informants hunted near Amadjuak Lake from the mid-1960s to the mid-1970s. From the late 1970s until the early 1990s, the winter range of caribou was similar to earlier distributions, and abundance gradually increased during this latter pe$\operatorname{riod}(\mathrm{JE}, \mathrm{SK}$, Fig. 7E).

\section{Nettilling Lake Hunting Region}

The plains north of the Koukdjuak River were an important summer caribou hunting area from c. 1916 (or before) until c. 1967 (EA, PA1, EN1, TM, Figs. 2-4). During c. 1916-23 many caribou occurred along the northwestern shore of Nettilling Lake (Fig. 2), but subsequently hunters had to travel at least $35 \mathrm{~km}$ to the coastal wetlands along Foxe Basin or to the Koukdjuak River before finding sufficient caribou (EN1, PA1). After c. 1924, either the overall abundance of caribou decreased, or caribou became more scattered near the lake in response to increasing numbers of hunters (PA1). Caribou abundance in summer was lowest during c. 1939-55 (PA1, Fig. 3). None of the elders reported a noticeable migration of caribou on the plains north of the Koukdjuak River before 
c. 1960 (AE, Fig. 4), not even during c. 1916-23 when abundance was high (EA). During July and August c. 1977 to c. 1982, MS saw many caribou crossing the eastern Koukdjuak River toward the south, and migrating eastward along the north shore of the river (Fig. 5).

During September and early October from c. 1916 (or before) until c. 1994, caribou migrated toward the southeast from northern Nettilling Lake across Camsell Bay (AE, EA, JE, JK1, MS, PA1, SK, TM, Figs. 2-6). Between c. 1924 and c. 1945, cows migrated through Camsell Bay mainly during September, while bulls occurred in southern Camsell Bay in August (EA, PA1, EN1, JE, TM). Compared with the 1940s, the numbers of migrating caribou had increased substantially by the 1970s (JE). During the early 1980s, cows started migrating southward across the bay in mid-August (JE, MS, Fig. 5).

From the mid-1920s (or before) until at least the early 1960s, caribou wintered south and east of southern Nettilling Lake (AE, EN2, JT2, LN1, PP, SQ, SR, Figs. 2-4). During April-May in those years, cows and some bulls migrated north toward Camsell Bay (AE, EN2, LN1, NI). Caribou apparently decreased around southern Nettilling Lake in winter during the late 1930s (NI, Fig. 3), but remained in numbers sufficient for the one family living there during c. 1944-49 (JT2).

During winter from c. 1916 to 1994 , several informants (AE, CA, EA, EK, JE, JK1, PA1, PA2, SK) hunted caribou migrating north across Camsell Bay in late winter and spring (Figs. 2-6). Before the 1920s, the number of caribou apparently was quite consistent (EA, Fig. 2), but from the early 1920 s to the mid-1950s, caribou abundance was highly variable; none were seen in some years because of increased annual variations in timing of the migration (PA1, Fig. 7F). From the mid-1960s to the mid-1980s, caribou abundance in Camsell Bay began to increase as caribou began to overwinter there (EN1, JE, Fig. 7F). The abundance of caribou overwintering in Camsell Bay had decreased noticeably by the early 1990s (SK, Figs. 6, 7F).

\section{Tassialukjuaq Hunting Region}

JK1's father saw caribou throughout the Tassialukjuaq region during c. $1900-10$, but from c. 1920 until c. 1955 caribou were seen rarely (CA, EA, EK, JE, JK1, JM, PA1, PA2, TM, Figs. 2, 3, 7G). Beginning in the late 1950s and early 1960 s, caribou were seen more often (EK, JE, JK1, SK, Fig. 4). Along Nettilling Fiord, caribou gradually increased in abundance and expanded their range towards the coast of Cumberland Sound from the 1960s into the 1980s (JE, SK, Figs. 4, 5). From c. 1951 to c. 1985, caribou also increased in numbers and expanded their distribution around the lake, Tassialukjuaq (JE, EK), but since winter c. 1985 caribou abundance has decreased markedly (JE, Figs. 6, 7G). As abundance decreased near Tassialukjuaq in the late 1980s, caribou began overwintering closer to Cumberland Sound, first appearing at the coast in winter c. 1989 (JK1, Fig. 6).

\section{Cumberland Peninsula Hunting Region}

During summer in the late 1800 s, caribou were rare near Clearwater Fiord, so hunters travelled about $75 \mathrm{~km}$ inland to the Penny Ice Cap to get enough caribou (JK1). Subsequently, northeastern Cumberland Sound became an important hunting area as caribou increased and expanded into this region from Tassialukjuaq during the 1910s (EA, EK, PA1). In the early 1920s, caribou were found on islands in northern Cumberland Sound throughout winter (EK, PA1, Fig. 2). Until the mid-1920s, many caribou migrated southeastward toward Pangnirtung during September-October, returning to the northwest during spring (EA, EK, PA1). During the same period, other caribou migrated north to summering areas south of the ice cap (EK). Winter c. 1925 was the last year that caribou were found extensively between Clearwater Fiord and Pangnirtung; after that, the remaining caribou migrated only to the north (CA, EK, PA1, PA2). During the 1930s, fewer caribou returned each autumn to the coast from the inland summering areas, and by the 1940s, only groups of $1-$ 2 caribou were seen occasionally near Clearwater Fiord during winter (EK, JK1, JM). No caribou were seen near Clearwater Fiord in winter between c. 1942 and c. 1962 (EK, Fig. 7G).

During summer in the early 1930 s, fewer caribou were seen near the Penny Ice Cap over $40 \mathrm{~km}$ inland (EK, Fig. 4). In the 1940s and 1950s, caribou were seen rarely within about $80 \mathrm{~km}$ of the coast in summer, and hunters often travelled inland to the plateau previously hunted by JK1's father in the late 1800s (CA, EK, JK1, PA1, Fig. 3)."There just was not any more caribou. In the winter, it touched all of us" because of inadequate supplies of caribou-skin clothing (EK).

After c. 1957, caribou slowly increased inland of Clearwater Fiord, but abundance was low and only bulls were found during winter (EK, JK1, JM). After c. 1962, distribution expanded noticeably in winter (EK, JK1), and the winter abundance of caribou increased, mainly in inland areas, until the late 1970s (CA, JK1, SK, Fig. 5). Then in the mid-1980s and 1990s, caribou abundance increased markedly along the coast (JK1, SK, Figs. 6, 7G). During c. 1990, caribou started migrating in large numbers from the northwest along Clearwater Fiord (JK1, SK). This northwest-southeast migration was similar to that observed before the 1930s. In winter 1994, caribou began wintering on islands in northeastern Cumberland Sound (JK1, SK). SK reported that "thousands" of caribou migrated from the west in autumn 1994.

Pangnirtung (Pangnirtuq, in Inuktitut) means place with mature male caribou. In the early 1900s, JK1's father hunted near Pangnirtung, finding many bulls in summer and early autumn (EK, Figs. 2, 3). The last caribou near Pangnirtung were seen during the early 1930s (EA, JM). The coastal area southeast of Pangnirtung was an important summer hunting area in the early 1900s (EA, EK, PA1, Fig. 2). In winter from c. 1923 to c. 1933, caribou were found in the valleys east of Pangnirtung and other fiords (EA). Only a few caribou remained in the valleys northeast of Pangnirtung in the 1940s (GU, Fig. 3). Nevertheless, 
more caribou apparently occurred on southeastern Cumberland Peninsula than near the coast of northern Cumberland Sound in the late 1940s (JM, PA1). In 1994, JK1 predicted that the caribou would soon migrate past Pangnirtung onto southeastern Cumberland Peninsula.

\section{Area Known by the Informants}

The informants did not know the entire potential range of South Baffin caribou in any period. Some areas were unknown to hunters in all seasons in all decades because of terrain ruggedness (SA1) or distance from the informants' homes (EK), while others were inaccessible only in some seasons (EK, SA1). The known area peaked at $98000 \mathrm{~km}^{2}$ during winter in the 1940s, when hunters had to search larger areas because caribou were scarce. The area known during winter was lowest when caribou were close to the coast; i.e., an average of $54000 \mathrm{~km}^{2}$ during winter $1910-23$ and $61000 \mathrm{~km}^{2}$ during winter 1970-93. During each decade, the area known during spring was $99-101 \%$ of that known during winter. The smallest known area occurred during autumn (50-67\% of winter), when travel becomes difficult during freeze-up. During decades when caribou were abundant and/or increasing (i.e., 1910 and 1950-93), the area known in summer was $61-71 \%$ of that known in winter. During the decline in caribou abundance during 1920-43, the known summer area was $82-84 \%$ of that in winter, reflecting the increased need to find caribou during summer before caribou distributions became scattered and unpredictable during winter.

Other factors also affected the size of the area known by the informants. Most informants were active hunters from c. 1940 until 1963, while the older informants provided most of the earlier information and the younger hunters provided most of the more recent observations. As well, during the early 1900 s, commercial whaling and sealing reduced the time available for caribou hunting in most seasons (EA). In the 1960s, movement into settlements, increasing employment, and a die-off of sled dogs similarly reduced the mobility of most informants. By the late 1960s, the snowmobile allowed hunters to explore some rugged and/or distant areas that had been less accessible by dog team (EK). These combined factors would have yielded a historical pattern of land use that was inconsistent with that described collectively by the informants. Therefore, we concluded that changes in the proximity of caribou to the coast during the 1900s were the major influences on the amount of area known by the informants as detected in this study.

\section{Population Trends of South Baffin Caribou}

Some informants assumed that when caribou decreased in their hunting region, they emigrated to another, resulting in no overall change in the total population. In other words, local subpopulations were cyclic, but the overall population may not be. However, as none of the informants hunted all regions, they did not have firsthand or parental knowledge to support such an assumption. Most hunters never knew where the caribou went once they became scarce (EK). Even though the overall abundance of caribou did change across southern Baffin Island, Inuit knowledge holds that caribou have never completely disappeared (LN1).

Although the timing of changes in caribou abundance varied somewhat from region to region (Fig. 7A-H), the trends in all regions did produce major fluctuations in the overall abundance of the whole population during the 1900s (Fig. 7I). The population apparently experienced a minimum average annual decrease of $9 \%$ (i.e., $\mathrm{r}=-0.089$ ) from 1910 to 1943; followed by a minimum average annual increase of $8 \%$ (i.e., $r=0.073$ ) from 1943 to 1983. The decline on Hall and Cumberland Peninsulas began about 10 years later than in other regions, but the subpopulations reached their lows in the 1940s, when the others did. Abundance began increasing in most areas in the 1950s, but the rates of increase varied among regions. Major increases in abundance in some regions in the 1990s could be explained only by immigration from adjacent regions. According to Inuit knowledge, the abundance seen in the 1990s probably represents a long-term population peak for South Baffin caribou.

Fluctuations in caribou abundance and distribution on southern Baffin Island occurred regularly over the lifetime of an elder (JP, LN1, NI, SA1), a period of 60-80 years. Keith (1974) called such predictable fluctuations "cyclic." The informants' elders, now dead, had accurately predicted changes in caribou abundance and distribution 30-80 years in advance, largely on the basis of the cyclic nature of the population (GU, LN1, NI, SR). For example, if caribou numbers were high when the informant was a child, he was then told that there would be very few caribou and he might face starvation while he was raising his children, but when he became an elder, caribou would once again become abundant. As children, several informants could not visualize the changes predicted by their elders, but they have seen most of these predictions fulfilled during their lives.

\section{DISCUSSION}

Several types of recollections indirectly suggested changes in abundance and distribution of caribou, including changes in hunting areas, age when the informant first saw or tasted caribou, ability to obtain sufficient skins or meat, references to being cold during winter, and dependence on outside sources of caribou skins or meat. However, such recollections do not necessarily indicate changes in caribou populations, because they can also be caused by illness, moving to a new residence (e.g., after a marriage), lack of hunting equipment (e.g., bullets), sled dog epizootics, and many other factors. The initial discussion of an informant's biography usually revealed contextual information about such factors (Ferguson and Messier, 1997). Whenever an informant directly or indirectly implied a population change among caribou, we asked several questions to refine the observed distribution of caribou and to directly compare the 
abundance with other areas and periods with which the informant was familiar.

Inuit knowledge described changes in the South Baffin population that were useful in predicting future changes because of their sequential pattern:

1. During periods of maximal caribou abundance, some wintering areas are used by cows exhibiting two distinct migratory patterns.

2. Before caribou decrease, they occupy small islands several $\mathrm{km}$ off Baffin Island, and feed on very steep terrain.

3. Caribou in a given wintering area usually decrease (or increase) between subsequent winters as fewer caribou (or more) return from their summering areas.

4. Sometimes subpopulations emigrate en masse to adjacent areas where a new winter range is established ("range shift").

5. During a decline and subsequent population low, caribou distributions become scattered and unpredictable from year to year ("range volatility"), except during summer west of Nettilling Lake.

6. During population lows, caribou are reliably found only in special areas, but both group size and group density are low.

7. During population increases, caribou re-occupy wintering areas abandoned for several decades, and then expand their range into adjacent areas ("range expansion").

8. Later in the increase phase, the winter range expands on one front, but contracts on other fronts ("range drift").

\section{South Baffin Caribou, 1900-30}

South Baffin caribou were at or near peak abundance during 1910-13, and subsequently declined to a low in the early 1940s (Fig. 7). In 1915, Duval estimated one million caribou on Baffin Island, and in 1925 Burwash suggested that each of five caribou populations contained many thousands (cited in MacPherson, 1963). Although unreliable, these estimates generally corroborate the abundance of caribou reported by Inuit about 60 years later. Written reports confirm that caribou occurred along the coast and islands of Hudson Strait in 1897, and inland on Foxe and Meta Incognita Peninsulas and near Mingo and Amadjuak Lakes at least until c. 1920 (CDMF, 1898; Bell, 1901; Fleming, 1910, 1911, 1930z; Fleming in Millward, 1930; Washburne and Anauta, 1940; Pitseolak and Eber, 1993). After low caribou abundance along western and northern Cumberland Sound from 1894 to 1909 (Hantzsch, 1977), caribou increased there 12 or more years later than along Hudson Strait. Subsequent reports by Soper $(1928)$ and RCMP $(1928,1932)$ corroborated Inuit knowledge that caribou were abundant on northern Cumberland Sound for no more than 20 years.

The virtual disappearance of caribou on Foxe Peninsula, the scarcity of caribou skins, and the change in caribou hunting areas to the north of Amadjuak Lake during the mid1920s were corroborated by Burwash (cited in Millward, 1930), Putnam (1928), RCMP (1928, 1930, 1931), and Soper $(1928,1944,1981)$. Starvation of an Inuit family after a failed caribou hunt in 1929 was reported by the RCMP (RCMP, 1931). Nevertheless, some Inuit knew where a few caribou occasionally occurred on Foxe Peninsula (OP, PP, SR; Soper, 1944). Caribou were more common (yet decreasing) on Meta Incognita Peninsula until 1927 (RCMP, 1927, 1928; Soper, 1928). By 1930, the HBC was importing caribou skins into Kimmirut from Alaska (Soper, 1981). On Hall Peninsula, supplies of caribou skins were generally inadequate after 1928, although 1930 was an exception (RCMP, 1928, 1929, 1930,1931 ) indicative of unpredictable caribou distributions during periods of decline.

During 1900-30, the abundance of caribou northwest of Nettilling Lake during summer and in eastern Nettilling Lake during autumn was also observed by non-Inuit in 1902, 1910, and 1925 (Soper, 1928; Millward, 1930; Hantzsch, 1977). Soper $(1928,1981)$ observed an abundance of caribou during the spring migration in eastern Nettilling Lake during the mid-1920s. Consistent with informants' reports, neither Hantzsch (1977) nor Soper (1928) reported caribou migrating across the Koukdjuak River during summer in 1910 or 1926, respectively. Hantzsch (1977) and Soper (1928) also reported that caribou abandoned the plains west of Nettilling Lake from late autumn to early spring.

Although this was not reported by the informants, the HBC encouraged Pangnirtung Inuit to kill more caribou than they needed to ship hides and sinew to Labrador during the early and mid-1920s (RCMP, 1926). As EK reported, the migration west of Pangnirtung changed in autumn 1925, making caribou clothing rare (RCMP, 1927). From 1925 into the 1930s, several RCMP officers reported that caribou or signs of caribou were found south and east of Pangnirtung (RCMP, 1928, 1930, 1932; Soper, 1928), although informants reported a general scarcity of caribou.

In summary, large increases near Cumberland Sound did not occur until c. 1910, as opposed to the late 1800s along the coast of Hudson Strait and Frobisher Bay. The subsequent decline of caribou occurred 5-10 years earlier on Foxe Peninsula (c. 1920) than on Meta Incognita (c. 1926) and Hall (c. 1928) Peninsulas. About 5-10 years before caribou decreased in each area, they began using smaller islands. The decline on Cumberland Peninsula was marked by a change in the dominant migratory pattern, and by the late 1920 s, caribou occurred mainly on eastern parts of the peninsula. As the decline began in most hunting regions, caribou abundance dropped within a few years, which suggests mass emigration. Although caribou abundance was higher near Nettilling Lake than elsewhere by the late 1920s, signs of decline also appeared in that region. By the late 1920s, winter ranges had become unpredictable except on eastern Cumberland Peninsula. Despite the overall decline, some caribou persisted within all hunting regions at the end of this period.

\section{South Baffin Caribou, 1930-60}

Caribou across southern Baffin Island continued to decline during the 1930s, reached a low in the 1940s, and began a slow recovery in the 1950s (Figs. 2, 7). Throughout this 
period, caribou were generally rare, and their distribution was unpredictable, even during summer. Special areas described by the informants' elders were the only areas where some caribou could be found reliably. Population estimates by nonInuit during this period (Manning, 1943; Wright, 1944; Kelsall, 1949; Tener and Solman, 1960; Turner to Berry, cited in MacPherson, 1963) generally confirm the low abundance, but are unreliable (MacPherson, 1963). After recalculating Tener and Solman's (1960) estimate, MacPherson (1963) suggested that only 25000 to 30000 caribou were living on all of Baffin Island in 1960, but their numbers were increasing rapidly. Although inadequate by current standards, aerial surveys by Kelsall (1949) and Tener and Solman (1960) confirmed some wintering areas identified by informants, missed areas known by the informants, and identified other areas unknown to the informants. Therefore, caribou distributions were greater than those known either to the informants in this study or to those who conducted the surveys.

By the early 1930s, the most severe decrease in caribou abundance had occurred from Foxe Peninsula east to Hall Peninsula. Most Inuit in these areas were wearing caribou parkas that were $2-5$ years old (RCMP, 1932, 1933). Some caribou occurred locally on Cumberland Peninsula in the 1930s (RCMP, 1932, 1933, 1937). Manning's (1943) descriptions of caribou distributions and abundance on southern Baffin Island during 1938-40 agreed with those of the informants, where their information overlapped.

Using RCMP questionnaires and HBC reports during the early 1940s, Wright (1944) concluded that caribou were very scarce or absent west of Meta Incognita Peninsula, when 15 Cape Dorset families were living near Amadjuak and Nettilling Lakes. As well, Cape Dorset Inuit traded 200 caribou skins annually with Inuit from Igloolik, and traders imported skins into Cape Dorset. A few small herds occurred on Meta Incognita Peninsula in spring 1942. Caribou were found about $120 \mathrm{~km}$ inland from Frobisher Bay and northwestern Cumberland Sound in autumn and early winter. Many caribou wintered near southern Nettilling Lake and summered on the coast of Foxe Basin. Wright's (1944) description of caribou distributions, although vague, agreed with the descriptions of those distributions by Inuit informants $40-50$ years later.

Inuit knowledge suggested that the caribou population increase did not begin in all hunting regions at the same time or at the same rate. Apparently increases began west of Cumberland Sound and around Nettilling Lake during the 1940s (Fig. 7E, 7F) and-as predicted-caribou increased near Mingo Lake a few years before caribou expanded onto Foxe Peninsula (Fig. 7A, 7B). By 1960, the increase and expansion were well underway near Mingo Lake and onto Foxe Peninsula, but had barely begun elsewhere.

\section{South Baffin Caribou, 1960-94}

Tener (1961), MacPherson (1963) and Chowns (1979) recognized some inadequacies in the design and execution of caribou surveys over Baffin Island. Estimates from incomplete surveys by Elliott and Elliott (1974) and Redhead
(1979) suggested no increase in caribou abundance since the early 1940s, and thus are incongruous with Inuit knowledge. In 1978, Chowns (1979) conducted the most accurate survey yet over some of southern Baffin Island, but he could not determine the population trend because of past and continuing survey problems. Nevertheless, Calef (1980) used Chowns's results to incorrectly conclude that caribou populations on Baffin Island were decreasing during the 1970s.

According to our compilation of Inuit observations, caribou abundance increased across most of southern Baffin Island from 1960 until the mid-1980s. Since then, caribou have either peaked or stabilized (Fig. 7I); Inuit knowledge suggests the former. Caribou winter ranges expanded from inland areas toward the coast; abundance increased at different rates in different regions; range expansion was followed by range drift as inland abundance decreased; and eventually caribou occupied small islands up to $20 \mathrm{~km}$ off the coast. On Foxe Peninsula, range drift was followed by a massive shift in winter distribution. The processes of range expansion and drift has occurred on Meta Incognita and Hall Peninsulas, and from northeastern Nettilling Lake to Tassialukjuaq to Cumberland Peninsula. Several informants have predicted that the process of range shift will occur in these areas within a few years.

Caribou on Foxe Peninsula increased and expanded throughout the 1960s (Rippin, 1972). A caribou ear-tagging project from 1974 to 1982 (Kraft, 1984; Ferguson, unpubl. data) and aerial surveys in 1978 (Chowns, 1979) and 1984 (Ferguson, unpubl. data) confirmed the expansion of winter range on the peninsula during the late 1970s and 1980s. About 3.5 caribou $/ \mathrm{km}^{2}$ occurred west of Meta Incognita Peninsula in autumn 1984. The emigration of caribou from Foxe Peninsula, predicted and subsequently observed by Inuit, was confirmed in April 1992, when only 0.2 caribou/ $\mathrm{km}^{2}$ were observed during an aerial survey (Ferguson, unpubl. data).

Caribou increased more slowly on Meta Incognita Peninsula than on Foxe Peninsula from the 1950s until the late 1980s. During an aerial survey in March 1982, caribou were found at a density of $0.1 / \mathrm{km}^{2}$, mainly west of Kimmirut (Ferguson, unpubl. data). The sudden increase in winter abundance on Meta Incognita Peninsula in the late 1980s was corroborated in an April 1992 survey, when a density of 5.4 caribou/ $\mathrm{km}^{2}$ was found (Ferguson, unpubl. data).

Reports by Bourque (1975), Chowns (1980), and Chowns and Popko (1980) confirmed Inuit reports of caribou distributions in the Hall Peninsula region during the 1970s. Calving areas expanded from three watersheds in 1979 (Chowns and Popko, 1980) into two adjacent watersheds by 1982 (Ferguson, unpubl. data). During autumn 1984, caribou were concentrated from northern Frobisher Bay to $50 \mathrm{~km}$ inland (Ferguson, unpubl. data). By the early 1990s, their winter range was drifting into the town of Iqaluit and onto islands in northern Frobisher Bay.

Tener (1961), Rippin (1972), Elliott and Elliott (1974), Chowns (1979), and Ferguson (unpubl. data) confirmed that caribou continued to winter south of Nettilling Lake and 
along eastern Amadjuak Lake from c. 1960 to the early 1990s. The increase near Tassialukjuaq in the 1970s was confirmed by Elliott and Elliott (1974), Redhead (1976), and Chowns (1979). Ear-tag data (Ferguson, unpubl. data) corroborated that caribou from eastern Nettilling Lake wintered mainly near the coast of northern Cumberland Sound during the 1980s, and immigrated onto northwestern Cumberland Peninsula by the early 1990s. In April 1991, no sign of caribou was seen during an aerial survey (Ferguson, unpubl. data) on eastern Cumberland Peninsula, the only unoccupied area that Inuit predict caribou will soon occupy.

\section{Seasonal Migrations and Caribou Ecotypes}

As Baffin caribou migrate most extensively during seasons of snowmelt and snow accumulation, when travel on the land by humans is most restricted, firsthand knowledge of the migration is difficult to obtain. Soper (1928, 1944, 1981), Elliott and Elliott (1974), and Brody (1976) reported lengthy, often complicated migratory patterns of caribou on Baffin Island. In this study, informants' firsthand observations of migration were limited to a few tens of km (Figs. 2-6). When informants speculated about the destinations of migrating caribou, they did not suggest complicated scenarios like those of Soper (1928). Satellite telemetry is probably the only tool that could elucidate longer seasonal migrations of the various subpopulations.

The observations of the informants indicated that cows and immature caribou usually migrate inland away from wintering areas anytime between early March and late May and return between July and early December. Although cows usually occupy inland terrain more rugged than the coastal terrain used by bulls in winter, they too tend to move to coastal areas during periods of high abundance (e.g., 1910-23 and 1980-93). Also during periods of abundance, cows migrate inland later in spring and return earlier in summer or autumn. Bulls move inland during September, returning to their wintering and summering areas by early December. When cows and bulls were seen together during October and November, they were observed moving quickly over large areas. After the rut, mature cows and bulls remain segregated until the following autumn. Some bulls migrate inland in late spring or early summer, but apparently do not migrate as far as the females.

In summer, cows utilize wetlands along Foxe Basin and near large lakes and rivers on the peninsulas (Figs. 2-6). Thus, cows are widely scattered during summer, $10-400 \mathrm{~km}$ from known wintering areas. Bulls also distribute themselves widely across the island during summer, but usually remain on or within $100 \mathrm{~km}$ of their wintering areas.

Inuit observations of caribou distributions, seasonal migration patterns, and physical characteristics suggest that South Baffin caribou are composed of two distinct ecotypes, Natsilik and mountain, and several subpopulations. Some informants in all four settlements could distinguish migratory Natsilik (or Nettilling) caribou from resident mountain caribou. Natsilik cows exhibit the greatest migratory tendencies, usually migrating out of wintering areas earlier in spring and returning later in autumn than mountain caribou. Natsilik caribou also tended to utilize lower elevations year-round (i.e., uplands in winter and coastal wetlands in summer). In extremely mountainous terrain, mountain cows migrate to higher elevations, calving on snow-covered peaks and then congregating in snow-free valleys (AN; Soper, 1928). In other areas, mountain cows migrate inland in late spring and are found near lakes on high plateaux during summer.

Although CA, JK1, EK, EN1, KK, LN1, NI, SA2, and SQ recognized the two types of caribou by differences in migratory behaviours, EN1, KK, LN1, NI, and SQ also reported that Natsilik and mountain caribou differ physically. Natsilik caribou are smaller, with shorter legs. Reportedly, mountain caribou near Iqaluit are faster because of their longer, slender bodies and longer legs (LN1). LN1 and SQ thought that the Natsilik caribou were descendants of Norwegian reindeer transplanted to the Hudson Strait coast in the early 1920s; however EN1 disagreed, because the pelage of Natsilik caribou and the introduced reindeer differ.

Dominant migratory patterns in several areas changed as major changes in caribou abundance occurred. During the population high in 1910-23, both migratory patterns were observed near Clearwater Fiord (Fig. 2), but after abundance decreased in the 1930s, the remaining caribou migrated inland to higher elevations (EK), which is consistent with the behaviour of mountain caribou (Figs. 3-5). In the late 1980s, both migratory patterns reappeared in this area as caribou abundance increased in the area (JK1, SK). In the 1990s, after continued increases, the northwestward movement, characteristic of Natsilik caribou, dominated (SK), as in the 1920s (EK) (Fig. 6). Similar shifts in dominant patterns were also observed on Foxe Peninsula in the early 1980s (SQ), on Meta Incognita Peninsula in the early 1990s (SA2), and near northern Frobisher Bay during the 1980s and 1990s (KK, LN1, NI). Although the Natsilik migration pattern dominated after rapid population increases, informants reported that the less dense population of mountain caribou continued its traditional migrations. During population lows, the migrations of mountain caribou dominate in areas where caribou can be found, except around Nettilling Lake.

\section{Caribou Population Cycles and Inuit Predictions}

The compiled information from all Inuit informants suggested a period of 60-80 years between peak population levels during the 1900s (Fig. 7). Although personal and parental observations can document only the past 90 years, Inuit knowledge holds that fluctuations in the South Baffin caribou population are cyclic; i.e., they repeat at regular intervals equal to the life span of an elder. All informants found this periodicity to be dependable, as predictions made by their elders corresponded to their own subsequent observations. By backdating the periodicity of the caribou population fluctuations, we estimate that the previous population low should have occurred sometime during 1865-85 and the previous high, during 1835-55. 
Caribou were rare in coastal areas during winter in the late 1870s and 1880s (Tyson, 1879; CDM, 1886, 1887; Boas, 1974; Abbes, 1992). During 1876-78, Kumlien (1879) reported that caribou numbers had declined in previous years on Cumberland Peninsula and northern Cumberland Sound. Bulls "no longer" lived near Pangnirtung in the early 1880s (Müller-Wille, 1994), and Inuit from Cumberland Sound had to make extensive trips inland to hunt caribou (Kumlien, 1879; Tyson, 1879; Boas, 1974). In the early 1880s, the supply of caribou skins in some winters was deficient (Boas, 1974). Inuit from Cumberland Sound, Hudson Strait, and Frobisher Bay sometimes met while hunting caribou near Nettilling and Amadjuak Lakes (Boas, 1974). Ashe (CDM, 1886) and Tyrell (CDM, 1887) recorded no observations of caribou while on Big Island during 1884-86. These caribou distributions and Inuit hunting patterns during the late $1870 \mathrm{~s}$ and 1880s were similar to those observed during the population low in the 1940s, thus apparently corroborating the hypothesized periodicity.

Hall (1864) lived on Hall Peninsula during 1860-62, shortly after the estimated timing for previous peak (i.e., 1835-55). His reports suggested that caribou populations were in the late stages of a population peak, i.e., similar to that in the mid-1920s and the early 1990s. Apparently, caribou had been abundant along the coast before his arrival. Several years before Hall's visit, caribou had been very numerous on Resolution Island, about $25 \mathrm{~km}$ off Baffin Island in Hudson Strait (Sharkey in Hall, 1864). In June 1861, Hall (1864) saw recent traces but no caribou on a small island about $45 \mathrm{~km}$ from Hall Peninsula in Davis Strait. During 1860-62, summer distributions in Frobisher Bay were similar to those in the early 1990s. By late August, Inuit had caribou skins "in immense numbers," and bulls were common along northern Frobisher Bay, including the present site of Iqaluit. On the plateau of Hall Peninsula, Inuit could catch many caribou, which were as dense as the flocks of sheep seen by Tukulitu on the British Isles (Hall, 1864).

Although the written records from the 1800s are limited spatially and temporally, they generally support Inuit knowledge that South Baffin caribou populations follow a regular abundance and movement cycle over periods of 60-80 years.

\section{Future Directions}

MacPherson (1963) examined previous written descriptions of population trends and movements among South Baffin caribou, and found many of them flawed. Given evidence of the inherent accuracy and precision of Inuit recollections as reported in this paper and by Ferguson and Messier (1997), the present account of historical caribou distributions, abundance, and migrations on southern Baffin Island establishes a vital baseline for the future management of this caribou population.

The data from this study highlighted major differences between the Inuit concept of caribou populations and that used commonly by caribou biologists. The Inuit apparently view caribou in biological units, each unit moving together, sharing common behavioural and physical characteristics, but not being tied to a specific geographical area. According to the informants, a given geographic area can be occupied by two distinct units or populations at the same time. Most informants suggested that when caribou decreased in one hunting area, they emigrated to another area; i.e., the population may not have decreased; it just moved.

This initial conclusion by Inuit opposes that of biologists, who often define a population as members of a species occupying a particular area; i.e., as a geographical rather than a biological unit (Futuyma, 1986; Krebs, 1985; Wilson, 1980). Many biologists view decreasing abundance in a specific area as a population decline. Thomas (1969) delineated caribou populations (or "herds") on the basis of identifiable calving grounds where caribou aggregations could be surveyed efficiently. Such delineation would agree with that of the Inuit only if the vast majority of cows showed longterm fidelity to their calving grounds. However, Inuit in Baker Lake explained the 1970s decline of the Kaminuriak herd through emigration of some caribou to other calving grounds (Heard and Calef, 1986). Gunn and Miller (1986) found insufficient scientific evidence to reject fidelity of caribou, but Heard and Calef (1986) had to use immigration to explain an "unanticipated" $315 \%$ increase in the herd between 1980 and 1982. Subsequent radiotelemetry studies suggested that about $85 \%$ of Kaminuriak cows showed fidelity to the calving ground during 1985 and 1988, leaving Heard and Stenhouse (1992) with insufficient evidence to explain the initial increase of the early 1980s. The problem may have been that the telemetry research and changes in caribou distribution did not coincide.

Keith's (1974) definition of a population as a "group of individuals" does not tie delineation of a given population to a geographic area; the definition could include a mobile biological unit, as in the Inuit view. The Inuit concept also has similarities to the concept of "metapopulation," a population composed of local populations tied together by immigration and emigration (Hanski and Gilpin, 1991; Wells and Richmond, 1995). Current metapopulation models mainly address the rates of extinction of local populations and the colonization of unoccupied habitats through immigration. Baffin Inuit suggested that although local populations change in abundance, these groups emigrate to other habitats before becoming extinct, rather than reaching extinction on site, as presumed in metapopulation models. As well, metapopulation models deal with "spatially disjunct" groups (Wells and Richmond, 1995), and thus do not currently account for the Inuit distinction between groups of caribou that may cohabit during the rut and winter, but have differing migratory patterns during other seasons.

By integrating Inuit knowledge that may describe future distribution changes with some accuracy, biologists could develop and test predictive models for caribou populations that incorporate the phenomena of range expansion, drift, shift, and volatility. Although most Inuit apparently base their predictions on the sequence of population changes described by their elders, some have suggested factors that 
apparently cause these changes (Ferguson, unpubl. data). Once these insights are integrated into predictive population models, caribou managers will be able to take proactive measures that consider both future caribou population changes and their proximal causes, rather than reacting to past trends that may not continue in the future. The potential for anthropogenically accelerated climate change makes collaboration between caribou biologists, other scientists, and the Inuit especially urgent (Ferguson, 1997).

Inuit will have a permanent role in the management of wildlife in Nunavut (Nunavut Final Agreement, 1993), and could incorporate their knowledge into population management with or without the cooperation of wildlife biologists. However, wherever indigenous peoples have occupied remote regions for several generations, their ecological knowledge probably has a broader temporal and spatial context than that of scientific surveys of wildlife populations. Careful and culturally appropriate compilation of indigenous ecological knowledge should provide important insights for wildlife ecologists and managers throughout the world.

\section{ACKNOWLEDGEMENTS}

We are most grateful to all the informants and interviewers listed in Table 1. We appreciate the support provided by the HTOs in Pangnirtung, Iqaluit, Kimmirut, and Cape Dorset. We thank the following agencies for financial and/or logistical support: NWT Environmental Action Program, Indian and Northern Affairs Canada; Iqaluit Research Centre, Science Institute of the NWT; Arctic Institute of North America; Beverly and Qamanirjuaq Caribou Management Board; Auyuittuq National Park Reserve; and Angmarlik Interpretive Centre. Tapes were translated and transcribed into English by Jonah Kilabuk, Nellie Sangoya, and Joe Enook. We appreciate the valuable research assistance and materials provided by Tammy Hannibal of HBC Archives. We thank M. Ferguson, P. Usher, J. Kruse, D. Clark, and an anonymous reviewer for their helpful comments on this manuscript. Many persons provided valuable assistance during this study, but special thanks go to S. Alainga, T. Akavak, T. Alareak, E. Coleman, D. Dyck, C. Eisan, N. Fortier, M. Karpik, H. Myers, J. Noble, and J. Ryan. Wildlife research permits were issued annually for this study as part of other research on the South Baffin caribou population.

\section{REFERENCES}

ABBES, H. 1992. The German Expedition of the First International Polar Year to Cumberland Sound, Baffin Island, 1882-83. Polar Geography and Geology 16:272-304.

ARIMA, E.Y. 1976. An assessment of the reliability of informant recall. In: Freeman, M.M.R., ed. Report of the Inuit land use and occupancy project. Vol. 2: Supporting studies. Ottawa: Indian and Northern Affairs Canada. 31-38.

BELL, R. 1901. A survey in Baffinland, with a short description of the country. The Geographical Journal 18:25-46.
BERKES, F. 1993. Traditional ecological knowledge in perspective. In: Inglis, J.T., ed. Traditional ecological knowledge: Concepts and cases. Ottawa: International Program on Traditional Ecological Knowledge and International Development Research Centre. 1-9.

BOAS, F. 1974. The central Eskimo. Toronto: Coles.

BOURQUE, A.L. 1975. Caribou observations, south Baffin Island, 1971-1975. Renewable Resources unpubl. report. Available at Renewable Resources Library, Government of the NWT, Yellowknife, Northwest Territories X1A 3S8, Canada.

BRODY, H. 1976. Land occupancy: Inuit perceptions. In: Freeman, M.M.R., ed. Report of the Inuit land use and occupancy project. Vol. 1: Land use and occupancy. Ottawa: Indian and Northern Affairs Canada. 185-242.

CALEF, G.W. 1980. Status of Rangifer in Canada. II. Status of Rangifer in the Northwest Territories. In: Reimers, E., Gaare, E., and Skjenneberg, S., eds. Proceedings of the Second International Reindeer/Caribou Symposium. Trondheim: Direktoratet for vilt og ferskvannsfisk. 754-759.

CAUGHLEY, G. 1977. Analysis of vertebrate populations. Chichester: John Wiley and Sons.

CDM (CANADA DEPARTMENT OF MARINE).1886. Report of the second Hudson's Bay Expedition under the command of Lieut. A.R. Gordon, R.N., 1885. Ottawa.

1887. Report of the Hudson's Bay Expedition of 1886 under the command of Lieut. A.R. Gordon, R.N. Ottawa.

CDMF (CANADA DEPARTMENT OF MARINE AND FISHERIES). 1898. Report of the expedition to Hudson Bay and Cumberland Gulf in the steamship Diana under the command of William Wakeham, Marine and Fisheries Canada, in the year 1897. Ottawa: S.E. Dawson.

CHOWNS, T. 1979. Wintering ground survey, South Baffin caribou herd, November 1978. Renewable Resources unpubl. report. Available at Renewable Resources Library, Government of the NWT, Yellowknife, Northwest Territories X1A 3S8, Canada.

1980. Brevoort Island area caribou survey, SeptemberNovember 1978. Renewable Resources, Government of the NWT File Report No. 5.

CHOWNS, T., and POPKO, R. 1980. A calving ground survey of the Hall Peninsula caribou herd, June 1979. Renewable Resources, Government of the NWT File Report No. 8.

CRÊTE, M., and PAYETTE, S. 1990. Climatic changes and caribou abundance in northern Quebec over the last century. Rangifer, Special Issue No. 3: 159-165.

ELLIOTT, R.C., and ELLIOTT, C.E. 1974. Baffin Island caribou surveys. Renewable Resources unpubl. report. Available at Renewable Resources Library, Government of the NWT, Yellowknife, Northwest Territories X1A 3S8, Canada.

FEIT, H.A. 1988. Self-management and state-management: Forms of knowing and managing northern wildlife. In: Freeman, M.M.R., and Carbyn, L.N., eds. Traditional knowledge and renewable resource management in northern regions. Edmonton, Alberta: IUCN Commission on Ecology and the Boreal Institute for Northern Studies. 72-91. 
FERGUSON, M.A.D. 1989. Baffin Island. In: Hall, E., ed. People and caribou in the Northwest Territories. Yellowknife: Renewable Resources, Government of the NWT. 141-149.

1997. Arctic tundra caribou and climate change: Questions of temporal and spatial scales. Geoscience Canada 23:245-252.

FERGUSON, M.A.D., and MESSIER, F. 1997. Collection and analysis of traditional ecological knowledge about a population of Arctic tundra caribou. Arctic 50:17-28.

FLEMING, A.L. 1910. The Arctic wilds for Christ: Second circular letter. Lake Harbour, Northwest Territories: Mission Station.

- 1911. The Arctic wilds for Christ: Third circular letter.

Lake Harbour, Northwest Territories: Mission Station.

- 1930z. The hunter - home or Joseph Pudlo: A life obedient to a commanding purpose. Toronto: Missionary Society, Church of England in Canada.

FREEMAN, M.M.R. 1975. Assessing movement in an Arctic caribou population. Journal of Environmental Management 3:251-257.

. 1985. Appeal to tradition: Different perspectives on Arctic wildlife management. In: Brøsted, J., Dahl, J., Gray, A., Gulløv, H.C., Henriksen, G., Jorgensen, J.B., and Kleivan, I., eds. Native power: The quest for autonomy and nationhood of indigenous peoples. Bergen, Norway: Universitetsforlaget AS. $264-281$.

FUTUYMA, D.J. 1986. Evolutionary biology. 2nd ed. Sunderland, Massachusetts: Sinauer Associated, Inc.

GUNN, A., and MILLER, F.L. 1986. Traditional behaviour and fidelity to caribou calving grounds by barren-ground caribou. Rangifer, Special Issue No. 1:151-158.

GUNN, A., ARLOOKTOO, G., and KAOMAYOK, D. 1988. The contribution of the ecological knowledge of Inuit to wildlife management in the Northwest Territories. In: Freeman, M.M.R., and Carbyn, L.N., eds. Traditional knowledge and renewable resource management in northern regions. Edmonton, Alberta: IUCN Commission on Ecology and the Boreal Institute for Northern Studies. 22-28.

HALL, C.F. 1864. Life with the Esquimaux: A narrative of arctic experience in search of survivors of Sir John Franklin's Expedition. 2 vols. London: Sampson Low, Son and Marston. $676 \mathrm{p}$.

-1873. Geographical discoveries in the Arctic regions. Journal of the American Geographical Society of New York 3:216221.

HANSKI, I., and GILPIN, M. 1991. Metapopulation dynamics: Brief history and conceptual domain. Biological Journal of the Linnean Society 42:3-16.

HANTZSCH, B. 1977. My life among the Eskimos: Baffinland journeys in the years 1909 to 1911. Translated and edited by L.H. Neatby. Mawdsley Memoir 3. Saskatoon: University of Saskatchewan.

HEARD, D.C., and CALEF, G.W. 1986. Population dynamics of the Kaminuriak caribou herd, 1968-1985. Rangifer, Special Issue No. 1:159-166.

HEARD, D.C., and STENHOUSE, G.B. 1992. Herd identity and calving ground fidelity of caribou in the Keewatin District of the Northwest Territories. Renewable Resources, Government of the NWT File Report No. 101.
JOHANNES, R.E. 1980. Using knowledge of the reproductive behavior of reef and lagoon fishes to improve fishing yields. In: Bardach, J.E., Magnuson, J.J., May, R.C., and Reinhart, J.M., eds. Fish behavior and its use in the capture and culture of fishes. ICLARM Conference Proceedings 5. Manila, Philippines: International Center for Living Aquatic Resources Management. 247-270.

KEITH, L.B. 1974. Some features of population dynamics in mammals. Transactions of the Eleventh International Congress of Game Biologists. 17-57.

KEITH, L.B., and WINDBERG, L.A. 1978. A demographic analysis of the snowshoe hare cycle. Wildlife Monographs No. 58.

KELSALL, J.P. 1949. Baffin Island caribou survey with population estimates and recommendations. Canadian Wildlife Service unpubl. report. Available at Renewable Resources Library, Government of the NWT, Yellowknife, Northwest Territories X1A 3S8, Canada.

KRAFT, P.G. 1984. Caribou tagging on the Koukdjuak River, Baffin Island, N.W.T.: A summary and analysis of tag returns. Renewable Resources, Government of the NWT Progress Report No. 10.

KREBS, C.J. 1985. Ecology: The experimental analysis of distribution and abundance. 3rd ed. New York: Harper and Row.

KUMLIEN, L. 1879. Contributions to the natural history of Arctic America, made in connection with the Howgate Polar Expedition, 1877-78. Bulletin of the United States National Museum 15. $179 \mathrm{p}$.

MACPHERSON, A.H. 1963. The caribou of Baffin Island, An unknown quantity. A brief review of published and manuscript data on numbers and distribution, requested by A.G. Loughrey, Acting Superintendent, Eastern Region, on September, 1963. Canadian Wildlife Service unpublished report. Available at Renewable Resources Library, Government of the NWT, Yellowknife, Northwest Territories X1A 3S8, Canada.

MANNING, T.H. 1943. Notes on the mammals of south and central west Baffin Island. Journal of Mammalogy 24:47-59.

MELDGAARD, M. 1986. The Greenland caribou: Zoogeography, taxonomy, and population dynamics. Meddelelser om Grønland, Bioscience No. 20.

MESSIER, F., HUOT, J., LE HENAFF, D., and LUTTICH, S. 1988. Demography of the George River caribou herd: Evidence of population regulation by forage exploitation and range expansion. Arctic 41:279-297.

MILLER, F.L. 1991. Estimating Bathurst Island Peary caribou and muskox populations. Arctic 44:57-62.

MILLER, F.L., RUSSELL, R.H., and GUNN, A. 1977. Distributions, movements and numbers of Peary caribou and muskoxen on western Queen Elizabeth Islands, Northwest Territories, 1972 74. Canadian Wildlife Service Report Series No. 40.

MILLWARD, A.E., ed. 1930. Southern Baffin Island: An account of exploration, investigation and settlement during the past fifty years. Ottawa: Department of the Interior.

MÜLLER-WILLE, L. 1994. Franz Boas with the Inuit of Baffin Island 1883-1884: Journals and letters. Berlin: Reinhold Schletzer Verlag. Unpubl. translation by W. Barr. Available at Department of Geography, University of Saskatchewan, Saskatoon, Saskatchewan S7N 0W0, Canada. 
NAKASHIMA, D.J. 1993. Astute observers on the sea ice edge: Inuit knowledge as a basis for Arctic co-management. In: Inglis, J.T., ed. Traditional ecological knowledge: Concepts and cases. Ottawa: International Program on Traditional Ecological Knowledge and International Development Research Centre. 99-110.

NUNAVUT FINAL AGREEMENT. 1993. Agreement between the Inuit of the Nunavut settlement area and her Majesty the Queen in right of Canada. Ottawa: Indian Affairs and Northern Development Canada and the Tungavik Federation of Nunavut.

PARKER, G.R. 1972. Biology of the Kaminuriak population of barren-ground caribou. Part 1: Total numbers, mortality, recruitment and seasonal distribution. Canadian Wildlife Service Report Series No. 20.

PITSEOLAK, P., and EBER, D.H. 1993. People from our side. Montreal: McGill-Queen's University Press.

PUTNAM, G.P. 1928. The Putnam Baffin Island Expedition. Geographical Review 18:1-40.

RCMP(ROYALCANADIANMOUNTED POLICE). 1926. Report of the Royal Canadian Mounted Police for the year ended September 30, 1925. Ottawa: King's Printer.

- 1927. Report of the Royal Canadian Mounted Police for the year ended September 30, 1926. Ottawa: King's Printer.

- 1928. Report of the Royal Canadian Mounted Police for the year ended September 30, 1927. Ottawa: King's Printer.

- 1929. Report of the Royal Canadian Mounted Police for the year ended September 30, 1928. Ottawa: King's Printer. . 1930. Report of the Royal Canadian Mounted Police for the year ended September 30, 1929. Ottawa: King's Printer. . 1931. Report of the Royal Canadian Mounted Police for the year ended September 30, 1930. Ottawa: King's Printer.

- 1932. Report of the Royal Canadian Mounted Police for the year ended September 30, 1931. Ottawa: King's Printer.

- 1933. Report of the Royal Canadian Mounted Police for the year ended September 30, 1932. Ottawa: King's Printer.

- 1937. Report of the Royal Canadian Mounted Police for the year ended March 31, 1937. Ottawa: King's Printer.

REDHEAD, R. 1976. Caribou survey in the Nettilling Lake and Amittok Lake areas (May 11-15, 1976). Government of the NWT unpubl. report. Available at Renewable Resources Library, Government of the NWT, Yellowknife, Northwest Territories X1A 3S8, Canada.

1979. An aerial survey of part of the South Baffin caribou herd 1976. Government of the NWT unpubl. report. Available at Renewable Resources Library, Government of the NWT, Yellowknife, Northwest Territories X1A 3S8, Canada.
RIPPIN, B. 1972. Baffin Island caribou: Report on aerial survey, May 1972 and a summary of known facts of caribou on Baffin Island. Government of the NWT unpubl. report. Available at Renewable Resources Library, Government of the NWT, Yellowknife, Northwest Territories X1A 3S8, Canada.

SKOOG, R.O. 1968. Ecology of the caribou (Rangifer tarandus granti) in Alaska. Unpublished Ph.D. thesis, University of California, Berkeley.

SOPER, J.D. 1928. A faunal investigation of southern Baffin Island. National Museum of Canada Bulletin No. 53, Biological Series No. 15. 1944. The mammals of southern Baffin Island, Northwest Territories, Canada. Journal of Mammalogy 25:21 - 254. .1981. Canadian Arctic recollections: Baffin Island 1923 31. Saskatoon: University of Saskatchewan.

STENTON, D.R. 1991. Caribou population dynamics and Thule culture adaptations on southern Baffin Island, N.W.T. Arctic Anthropology 28:15-43.

TENER, J.S. 1961. Baffin Island caribou survey, 1961. Canadian Wildlife Service unpublished report. Available at Renewable Resources Library, Government of the NWT, Yellowknife, Northwest Territories X1A 3S8, Canada.

- 1963. Queen Elizabeth Islands game survey, 1961. Canadian Wildlife Service Occasional Paper No. 4.

TENER, J.S., and SOLMAN, V.E.F. 1960. Aerial survey of Baffin Island caribou, March 16-22, 1960. Canadian Wildlife Service unpubl. report. Available at Renewable Resources Library, Government of the NWT, Yellowknife, Northwest Territories X1A 3S8, Canada.

THOMAS, D.C. 1969. Population estimates and distribution of barren-ground caribou in Mackenzie District, N.W.T., Saskatchewan and Alberta-March to May 1967. Canadian Wildlife Service Report Series No. 9.

TYSON, G.E. 1879. The cruise of the Florence; or, extracts from the journal of the Preliminary Arctic Expedition of 1877-78. Edited by H.W. Howgate. Washington, D.C.: James J. Chapman.

WASHBURNE, H.C., and ANAUTA. 1940. Land of the good shadows: The life story of Anauta, an Eskimo woman. New York: John Day Company.

WELLS, J.V., and RICHMOND, M.E. 1995. Populations, metapopulations, and species populations: What are they and who should care? Wildlife Society Bulletin 23:458-462.

WILSON, E.O. 1980. Sociobiology. Cambridge, Massachusetts: Harvard University Press.

WRIGHT, J.G. 1944. Economic wildlife of Canada's eastern ArcticCaribou. Canadian Geographical Journal 29:184-195. 